\title{
Türk Dünyasında Turizmin Ülkeler Arası İş Birliği Temelli Geliştirilmesine Yönelik Nitel Bir Araştırma*
}

Muharrem Tuna**

Başak Özyurt ${ }^{* * *}$

Ayşe Selin Dülger

Fatih Türkmen ${ }^{* *}$

Necmi Uyanık

Öz

Araştırmanın temel amacı, Azerbaycan, Kazakistan, Kırgızistan, KKTC, Özbekistan ve Türkiye Cumhuriyeti ülkelerinin mevcut potansiyellerinin belirlenip geliştirilmesi ile turizm alanında iş birliği yapılmasının önemini ortaya koymaktır. Bu çalışmada, örneklemin belirlenmesinde amaçlı örnekleme yöntemlerinden ölçüt örnekleme yöntemi ve maksimum çeşitlilik örnekleme yöntemi kullanılmıştır. Ayrıca, nitel araştırma desenlerinden durum çalışması kullanılmıştır. Çalışmada altı farklı Türk devletinin turizm akademisyenleri, bakan-

\footnotetext{
Geliş Tarihi: 31 Ocak 2021 - Kabul Tarihi: 20 Mayıs 2021

Bu makaleyi şu şekilde kaynak gösterebilirsiniz:

Tuna, Muharrem vd. "Türk Dünyasında Turizmin Ülkeler Arası İş Birliği Temelli Geliştirilmesine Yönelik Nitel Bir Araştırma.” bilig, no. 100, 2022, ss. 137-176.

* Prof. Dr., Ankara Hacı Bayram Veli Üniversitesi, Turizm Fakültesi, Turizm İşletmeciliği Bölümü Ankara/Türkiye

ORCID: 0000-0001-5526-7122

muharrem.tuna@hbv.edu.tr

*** Arş. Gör., Trakya Üniversitesi, Uygulamalı Bilimler Fakültesi, Turizm İşletmeciliği Bölümü Edirne/Türkiye ORCID: 0000-0003-3225-0250 basakozyurt1@trakya.edu.tr

-... Arş. Gör., Ankara Hacı Bayram Veli Üniversitesi, Turizm Fakültesi, Turizm İşletmeciliği Bölümü Ankara/Türkiye ORCID: 0000-0001-8897-013X ayse.dulger@hbv.edu.tr

Doç. Dr., Karabük Üniversitesi, Safranbolu Turizm Fakültesi, Turizm İşletmeciliği Bölümü Karabük/Türkiye ORCID: 0000-0001-6716-7399 fatihturkmen@karabuk.edu.tr

***** Prof. Dr., Selçuk Üniversitesi, Edebiyat Fakültesi, Tarih Bölümü - Konya/Türkiye ORCID: 0000-0003-3692-3168 necmiuyanik@hotmail.com
} 
lık temsilcileri ve turizm sektöründe çalışan yöneticilerinden oluşan 31 kişi ile derinlemesine görüşmeler gerçekleştirildikten sonra elde edilen verilerle MAXQDA 2020 nitel veri analiz programı kullanılarak tematik analiz yapılmıştır. Yapılan analizler neticesinde turizm alanında iş birliğinin Türk devletlerinde ekonomilerin iyileştirilmesi ve siyasi bütünlüğünün korunmasına katkı sağlayacağına; bu ülkelerdeki turizm destinasyonlarının çeşitli yollarla tanıtım ve pazarlamasının yapılması gerektiğine ve turizm iş birliğine yönelik bir çatı örgütün kurulmasına ihtiyaç olduğuna ulaşılmıştır.

\section{Anahtar Kelimeler}

Türk Devletleri, Türk Dünyası, turizm, iş birliği, turizm planlaması.

\section{Giriş}

Turizmin ülkeler üzerinde hem olumlu hem de olumsuz yönde ekonomik, sosyal ve çevresel boyutlarda çeşitli etkilerde bulunmaktadır. Ekonomik açıdan turizmin ülkelere sağladığı katkılar; istihdam yaratması, işgücü arzında artış sağlaması, yaşam standartlarını iyileştirmesi, döviz gelirlerini artırması, gayri safi millî hasılada artış sağlaması, bölgesel ihracat gelirlerini artırması şeklinde sıralanabilir (Marzuki 22). Bunlara ek olarak, turizm özellikle gelişmekte olan ülkelerde ödemeler dengesi üzerinde pozitif etki oluşturmaktadır. Bu etkinin sağlanabilmesi için ülkelerin turizm sektörlerini geliştirmeleri gerekmektedir. Söz konusu gelişim ise büyük ölçüde doğal ve kültürel çekiciliklere bağlıdır ve bu çekiciliklerin korunması ve geliştirilmesi oldukça önemlidir. Plansız ve aşırı düzeyde gerçekleşen turizm faaliyetleri çevre üzerinde su kirliliği, hava kirliliği gibi olumsuz etkiler oluşturmaktadır (Zhong vd. 2972). Turizmin ekonomik ve çevresel etkilerinin yanısıra sosyal bir olgu olması nedeniyle yerel kültür ve değerlere de önemli katkılar sağlamaktadır. Bireyleri ve toplumları birbirine yakınlaştırması da turizmin, önemli sosyal etkileri arasındadır (Akdağ vd. 1). Bu etkilerinin yanısıra, turizmin sosyal açıdan olumsuz bazı etkileri de bulunmaktadır. Turizmin gelişmeye başladığı destinasyonlarda yerel kültür farklı kültürlerden etkilenerek özgünlügünü yitirme tehlikesiyle karşı karşıya kalabilir. Bu nedenle turizmin sürdürülebilir bir anlayışla yapılarak ulusal ve yerel değerlerin korunmasına önem verilmesi gerekmektedir. Turizmin ülkelere sağladığı pozitif etkilerin uzun vadeli 
sürdürülebilirliği ise yöneticilerin ve turizm profesyonellerinin faydaları en üst düzeye çıkarma ve maliyetlerini en aza indirmelerine bağlıdır (Kreag 2).

Turizmin olumsuz etkilerinin azaltılarak olumlu etkilerinin artırılmasında kurumlar ve ülkeler arası iş birliğinin rolü önemlidir. Bütüncül bir turizm gelişiminin hedeflenmesi durumunda devlet kurumları arasında, farklı hükümet düzeyleri arasında, çeşitli idari düzeylerde, kamu ve özel sektör arasında iş birliği yapılması büyük önem taşımaktadır (Timothy 53). Bunun yanısıra, destinasyonlar arası iş birliği sadece birbirine yakın destinasyonlar arasında değil birbirinden uzak destinasyonlar arasında da yapılabilir. Destinasyonlar arasında ortak bir niş turizm türü veya tarihi bir ticaret rotası gibi doğrusal bir coğrafi özellik temelinde iş birliği sağlanabilir (Fyall vd. 20). Zemla (2014)'nın bu konuda yaptığı araştırmada, destinasyonlar arası iş birliği yapılmasının destinasyonların rekabet avantajlarının arttırılmasına izin verdiği vurgulanmıştır.

İşbirliği, bölgeler ve sektörler arasında sürdürülebilir büyümenin kilit bir faktörüdür (Ammirato vd. 217). Mikro açıdan düşünüldügünnde de işletmeler teknoloji geliştirmek ve rekabet üstünlügü elde etmek amacıyla iş birliği yaparak büyük avantajlar elde etmektedir (İlker 192). Bu hususa ülkeler aç1sından bakıldığında iş birliği yapılmasının taraf ülkelere ekonomik, kültürel ve siyasi açıdan çok sayıda katkı sağladığını söylemek mümkündür. Örnek verilecek olursa; Avrupa Birliğinde, birlik üyesi olan ülkelere hem ekonomik anlamda önemli derecede katkılar sağlanırken, hem de bünyesinde bulunan ülkeler arasında siyasi iş birliği güçlenmektedir. Türk devletleri gibi ortak tarihi geçmişe ve ortak kültürel mirasa sahip olan ülkeler arasında gerçekleştirilen işbirlikleri de taraf ülkelerin kalkınması, gelişmesi ve daha güçlü olması adına önem arz etmektedir.

Tarihsel geçmişlerine bakıldığında ortak dil, kültür ve tarihi paylaşan Azerbaycan, Kazakistan, Kırgızistan, Kuzey Kıbrıs Türk Cumhuriyeti, Özbekistan, Türkiye ve Türkmenistan’ın turizm alanında iş birliği yapması ise her bir ülkenin ekonomik ve sosyo-kültürel yönlerden gelişimine önemli katkılar sağlayacaktır. Bahsedilen ülkelerin mevcut turizm potansiyellerinin değerlendirilerek ortak turizm politikalarının izlenmesi, ortak turizm projelerinin tasarlanması ve hatta ortak turizm eğitimi ve öğretimi programlarının hazırlanması; bu kapsamda izlenecek yollar arasında yer almaktadır. Turizm alanında tüm bu işbirliklerinin yapılabilmesi için Türk devletlerinin 
gelişimini ve çıkarlarını esas alan bir yapılanmaya da ihtiyaç duyulmaktadır. Bu çalışmada da turizm alanında Türk Dünyası ülkelerinin mevcut durumu ele alınmış ve iş birliği temelli tüm ülkelerde turizmin gelişiminin ne şekilde sağlanabileceği sorusuna yanıt aranmıştır.

\section{Türk Dünyası Ülkeleri Arasında Turizm İşbirliği Yapılmasının Önemi}

1990’lı yılların başına kadar Türk dış politikasında yeri olmayan Orta Asya ülkeleri, Sovyetler Birliği’nin dağılması sonrasında bağımsızlıklarını ilan etmeleriyle birlikte Türkiye ile yakınlaşma sürecine girmişlerdir. Orta Asya Türk halkları ile Türkiye arasında bulunan ortak dil kullanımı ile kültürel, dini, etnik ve tarihi bağlar bu ilişkinin temelini oluşturmaktadır (Wheeler $3)$.

Ticaret, altyapı, enerji ve haberleşme; Türkiye'nin Orta Asya bölgesi ile ekonomik ilişkilerini derinleştirdiği sektörlerdir (Wheeler 8). Bununla birlikte ülkelere hem ekonomik hem de sosyo-kültürel anlamda pek çok katkı sağlayan turizm sektöründe Türk devletleri arasında işbirlği yapılması önemlidir. Sönmez ve Apostolopoulos (46), çalışmalarında ortak ticari girişimler gibi iş birliğine dayalı çalışmaların yapılması ile taraf toplumlar arasında ilişkilerin güçleneceğini vurgulamaktadırlar. Sancar vd. (292), Türkiye ve Orta Asya ülkelerinin ortak kökene sahip olmaları nedeniyle turizm konusunda ilişkilerini güçlendirmeleri özellikle kültür turizm potansiyellerini arttırmalarının ülke ekonomileri açısından oldukça önemli olduğu hususu üzerinde durmuşlardır. Gülcan (113) ise yaptığı araştırmada Türk dünyası ülkeleri arasındaki ilişkilerin geliştirilmesinde turizmin önemini vurgularken, ülkeler arasında iş birliğinin sadece ekonomik olarak değil kültürel yakınlaşmanın sağlanarak yapılması gerektiğini belirtmiştir. Yılmaz (411) araştırmasında, Türkiye ile Türk devletleri arasında turizm hareketini etkileyen coğrafi hareketleri incelemiş, ülkeler arasında turizm iş birliğinin sağlanması için turizm politikalarının geliştirilmesi gerektiğini ve ortak projeler sayesinde orta ve uzun vadede ülkeler arasında turizm hareketliliğinin sağlanacağını ifade etmiştir.

Ülkelere hem ekonomik hem de sosyo-kültürel anlamda pek çok katkı sağlayan turizm sektöründe Türk devletleri arasında işbirlği yapılması önemlidir. Türkmenistan ve KKTC hariç Türk Konseyi üyesi de olan Türk devletlerinin mevcut turizm potansiyelleri oldukça geniştir ve güçlüdür. $\mathrm{Bu}$ 
düşünce doğrultusunda 2014 yllında Bodrum'da düzenlenen Türk Konseyi Dördüncü Zirvesi "Turizm İşbirliği”" temasıyla gerçekleştirilmiştir (TÜRKKON). 4-5 Haziran 2014 tarihlerinde düzenlenen 4. Zirve Toplantısında “Turizm Ortak İşbirliği Protokolü” ile İpek Yolu üzerindeki Türk devletlerinin turizm destinasyonlarından oluşan "Türk Konseyi-Modern İpek Yolu” kapsamında tur paketi oluşturulması ve "Bölgesel Diaspora Merkezleri'nin" kurulması kararları alınmıştır (T.C. Dışişleri Bakanlığı).

\section{Türk Devletleri Arasında Gerçekleştirilen İşbirliği Çalışmaları}

Türk Konseyi (Türk Dili Konuşan Ülkeler İşbirliği Konseyi)

Türk Konseyi ya da diğer adıyla Türk Dili Konuşan Ülkeler İşbirliği Konseyi, 3 Ekim 2009 tarihinde kurulmuş olup merkezi İstanbul'dadır. Türk Konseyi'ne üye ülkeler Azerbaycan, Kazakistan, Kırgızistan, Türkiye, Özbekistan, Macaristan (Gözlemci Üye)'dir. Konsey, Türk devletleri arasında iş birliğini sağlayan çatı kuruluş olarak kabul edilmektedir. Türk Konseyi'nin ilişkili olduğu kurumlar ise aşağıda sıralanmıştır (T.C. Dışişleri Bakanlığı):

- TÜRKSOY (Uluslararası Türk Kültür Teşkilatı)

- TÜRKPA (Türk Dili Konuşan Ülkeler Parlamenter Asamblesi)

- Türk İş Konseyi

- Türk Akademisi

- Türk Kültür ve Miras Vakfi

- Türk Konseyi Ortak Ticaret ve Sanayi Odası

a. TÜRKSOY (Uluslararası Türk Kültürü Teşkilatı)

Türk halklarının ortak kültürünü yaşatmak, gelecek nesillere aktarmak ve dünyaya tanıtmak amaciyla kurulan TÜRKSOY, 1993 yılında faaliyetlerine başlamıştır. Teşkilatın kuruluş aşamasında Azerbaycan, Kazakistan, Kırgızistan, Özbekistan, Türkmenistan ve Türkiye Cumhuriyeti'nin Kültür ve Turizm bakanları anlaşma imzalamışlardır. Azerbaycan, Kazakistan, Kırgızistan, Özbekistan, Türkmenistan ve Türkiye Cumhuriyeti'nin kurucu ülkeler olduğu teşkilatın 8 gözlemci üyesi ile birlikte toplam 14 üyesi bulunmaktadır. Teşkilatın kurulduğu dönem ismi Türk Kültür ve Sanatları Ortak Yönetimi (TÜRKSOY) olarak belirlenmiştir. Fakat daha sonra yeni bir karar alınarak Uluslararası Türk Kültürü Teşkilatı olarak değiştirilmiş- 
tir. Teşkilatın Genel Sekreterliği Türkiye'nin başkenti Ankara'da olup başka herhangi bir ülke ya da şehirde temsilciliği bulunmamaktadır (TÜRKSOY).

\section{b. TÜRKPA (Türk Dili Konuşan Ülkeler Parlamenter Asamblesi)}

Merkezi Bakü'de bulunan TÜRKPA, 21 Kasım 2008 tarihinde Azerbaycan, Kazakistan, Kırgızistan ve Türkiye Cumhuriyeti Parlamento Başkanları'nın İstanbul Anlaşması'nı imzalamalarıyla kurulmuştur (TÜRKPA “Tarihçe”). Faaliyetlerini Türk Dili Konuşan Ülkeler Parlamentoları arasındaki iş birliğini sağlamak amacıyla sürdürmektedir (T.C. Dışişleri Bakanlığı).

\section{c. Türk $\dot{I}_{\xi}$ Konseyi}

Türk Konseyi tarafından gerçekleştirilen çalışmalar neticesinde, ülkeler arasında ekonomik iş birliğinin sağlanması amacıyla 2011 yılında kurulmuştur. Türk İş Konseyi'nin sekreteryası 2017 yılında alınan karar doğrultusunda İstanbul'da yer almaktadır. Türk Konseyi'ne üye olan ülkelerin oda başkanları, Türk İş Konseyi çatısı altında yılda bir kere biraraya gelmektedirler (T.C. Dışişleri Bakanlığı).

\section{d. Uluslararası Türk Akademisi (TWESCO)}

Uluslararası Türk Akademisi ilk olarak, 25 Mayıs 2010 tarihinde Kazakistan'ın başkenti Nur Sultan (o zamanki adıyla Astana)'da bulunan Barış ve Uzlaşma Sarayı'nda ulusal bir teşkilat olarak kurulmuştur. 2012 yılına gelindiğinde ise Azerbaycan, Kazakistan, Kırgızistan ve Türkiye ortaklığı ile uluslararası bir kuruluş olarak faaliyetlerini göstermeye başlamıştır. Türk devletleri arasında dil, edebiyat, kültür ve tarih alanlarında ortak bilimsel araştırmaların yapılmasını desteklemek ve Türk topluluklarının insanlığa olan katkısını değerlendirmek amacıyla kurulan Türk Akademisinin misyonu; Türk halklarının bilimsel kuruluşlarına bilim ve eğitim konusunda yardımcı olmak, Türk dilini konuşan ülkelerdeki aydınların girişimlerine destek vermek ve onları düzenli olarak bir araya getirmektir (TWESCO).

\section{e. Türk Kültür ve Miras Vakfı}

Türk Kültür ve Miras Vakfı 2012 yılında Türk Konseyi İkinci Zirvesi’nde kurulmuştur. Merkezi Azerbaycan'ın başkenti Bakü’dedir. Türk Kültür ve Miras Vakfı faaliyetlerini, Türk mirasının korunması ve üçüncü taraf ülkelerde ortaklık iş birliği çerçevesinde projelerin hayata geçirilmesi amacıyla sürdürmektedir (TÜRKPA “Türk”). 


\section{f. Türk Konseyi Ortak Ticaret ve Sanayi Odasi}

Türk Konseyi Ortak Ticaret ve Sanayi Odası, 17 Mayıs 2019 tarihinde Türk İş Konseyi üye kuruluşlarının başkanlarının katılımıyla Astana Ekonomik Forumu bünyesinde şekillendirilmiştir. Türk Konseyi Ortak Ticaret ve Sanayi Odası'nın uluslararası bir statü kazanmasına yönelik olarak da çalışmalar devam etmektedir (T.C. Dışişleri Bakanlığı).

Yukarıda sıralanan işbirlikleri Türk Dünyası Devletleri'nin farklı alanlarda ekonomik ve kültürel gelişimine katkılar sağlamaktadır. Bununla birlikte söz konusu ülkeler arasında turizme yönelik kurumsal iş birliği henüz kurulamamıştır. Bu çalışmanın sorunsalı Türk Dünyası ülkelerinin turizm alanında gelişimlerinin iş birliği temelli ne şekilde gerçekleştirilebileceğinin belirlenmesidir.

\section{Yöntem}

\section{Araştırma Deseni}

$\mathrm{Bu}$ çalışma nitel araştırma yöntem ve teknikleri kullanılarak yürütülmüştür. Nitel araştırma, bütüncül bir yaklaşımla katılımcıların bakış açısıyla olayları, algıları ve olguları anlama, betimleme ve analiz etme amacını taşıyan araştırma yöntemidir (Çokluk vd. 96). Nitel veri analizinde, veriler düzenlenmekte, birimlere ayrılmakta, sentezlenmekte, önemli rol oynayan değişkenler keşfedilmektedir. Nitel araştırmada araştırmacı, topladığı veriler içerisinde gizli duran bilgileri ortaya çıkarmaktadır (Özdemir 328). Bu çalışmada nitel araştırma desenlerinden durum çalışması deseni kullanılmıştır. Durum çalışması, sınırlı bir sistem, süreç, olay ya da durumu sistematik bir şekilde incelemeyi ve durumlara bağlı temaları belirleyip tanımlamayı amaçlamaktadır nitel araştırma desenidir (Subaşı ve Okumuş 420). Durum çalışması türlerinden ise "çoklu durum çalışması (çok vakalı çalışma)" yöntemi seçilmiştir. Bu araştırma yöntemi, birden fazla durum üzerinde veya ortamda çalışmayı kapsamaktadır (Aytaçlı 4, Ozan Leymun vd. 377). Bu doğrultuda bu çalışmada, 6 ülkenin (Türkiye, Azerbaycan, Kırgızistan, Kazakistan, Kuzey Kıbrıs Türk Cumhuriyeti ve Özbekistan) turizm sektörünün mevcut durumu derinlemesine incelenmiştir. 


\section{Çalışma Grubu}

Bu çalışmada, örneklemin belirlenmesinde amaçlı örnekleme yöntemlerinden ölçüt örnekleme yöntemi ve maksimum çeşitlilik örnekleme yöntemi kullanılmıştır. Ölçüt örnekleme yöntemini kullanan araştırmalarda katılımcılar belirli niteliklere sahip kişilerden oluşmaktadır. Bu nedenle, belirlenen ölçütlere (niteliklere) sahip kişiler çalışmanın örneklemine alınmaktadır (Yağar ve Dökme 4, Yaşar vd. 31, Büyüköztürk 11). Maksimum çeşitlilik örnekleminde katılımcıların çeşitliliğinin üst düzeyde olması amaçlanmaktadır (Kıroğlu, Kesten ve Elma 28). Bu çalışmanın örneklemini Türk Dünyası ülkeleri olan Azerbaycan, Kazakistan Kırgızistan Kuzey Kıbrıs Türk Cumhuriyeti, Özbekistan ve Türkiye'den akademisyenler, sektör temsilcileri ve bakanlık çalışanları olmak üzere üç farklı grup oluşturmaktadır. Araştırmaya bir Türk Dünyası ülkesi olan Türkmenistan ise veri toplamada karşılaşılan zorluklardan dolayı dahil edilememiştir. Bu çalışmada örneklem seçimindeki temel ölçüt, katılımcıların kendi ülkelerindeki turizm sektörünün güncel durumu hakkında yeterli bilgiye sahip olmasıdır. Akademisyenler, ülkelerin önde gelen üniversitelerin turizm bölümlerinden; sektör temsilcileri, ülkenin en etkili kuruluşlarının yöneticileri arasından; bakanlık temsilcileri ise, altı ülkenin ilgili bakanlıklarının görevlendirdikleri veya gayrıresmi olarak ulaşılabilen yöneticileri arasından belirlenmiştir. Çalışma grubu Türkiye (7 katılımc1), Azerbaycan (6 katılımcı), Özbekistan (4 katılımcı), Kazakistan (4 katılımcı), Kuzey Kıbrıs Türk Cumhuriyeti (4 katılımcı) ve Kırgızistan (6 katılımcı)'dan 10 kadın ve 21 erkek olmak üzere toplam 31 katılımcıdan oluşmuştur. Araştırma bulguları analiz edilirken kolaylık sağlaması açısından katılımcıların isimleri yerine kodlamaya gidilmiştir. Kodlamaya ilişkin bilgiler Tablo 1'de gösterilmektedir. 


\section{Tablo 1}

Katılımcıların Demografik Bulguları

\begin{tabular}{|c|c|c|c|}
\hline & $\begin{array}{c}\text { Kamu Sektörü } \\
\text { Turizm Paydaşları }\end{array}$ & $\begin{array}{c}\text { Özel Sektörü } \\
\text { Turizm Paydaşları }\end{array}$ & Akademisyenler \\
\hline \multirow{3}{*}{ Türkiye } & K5 / Erkek & K1 / Erkek & K4 / Erkek \\
\hline & K3 / Erkek & K2 / Erkek & K23 / Erkek \\
\hline & & & K24 / Erkek \\
\hline \multirow{3}{*}{ Özbekistan } & K9 / Kadın & K19 / Erkek & \\
\hline & & K10 / Kadın & \\
\hline & & K8 / Kadın & \\
\hline \multirow{3}{*}{ Kurgizistan } & K21 / Erkek & K7 / Kadın & K20 / Erkek \\
\hline & & K25 / Kadın & K26 / Kadın \\
\hline & & & K22 / Erkek \\
\hline \multirow{2}{*}{ Kazakistan } & K17 / Kadın & K27 / Erkek & K30 / Kadın \\
\hline & & K18 / Erkek & \\
\hline \multirow{2}{*}{ KKTC } & & K29 / Erkek & K31 / Erkek \\
\hline & & K6 / Erkek & K28 / Erkek \\
\hline \multirow{3}{*}{ Azerbaycan } & K14 / Erkek & K12 / Erkek & K13 / Kadın \\
\hline & & K15 / Erkek & K11 / Kadın \\
\hline & & & K16 / Erkek \\
\hline Toplam & 6 & 13 & 12 \\
\hline
\end{tabular}

Veri Toplama ve Analiz Yöntemi

Çalışmada nitel veri toplama yöntemlerinden yapılandırılmış görüşme tekniği kullanılmıştır. Araştırmanın soru setinde yarı-yapılandırılmış 10 adet soru mevcuttur. Sorular, ilgili literatür taranarak oluşturulmuştur (Erol, Çelik; Sancar vd.; Aydemir ve Yaşar; Zorlu). Veri toplama faaliyeti, 2020 yılının Eylül ve Ekim aylarında araştırmacılar tarafından internet üzerinden Zoom uygulaması kullanılarak yüz yüze ve e-posta aracılığıyla gerçekleştirilmiştir. Görüssmelerden elde edilen veriler ile MAXQDA 2020 nitel veri analiz programı kullanılarak tematik analiz yapılmıştır. Nitel veri analizlerinden tematik analiz (betimsel analiz), belirli bir çerçeve oluşturarak elde edilen verileri düzenlerek kategori ve temalar altında toplamayı amaçlamak- 
tadır (Braun ve Clarke 875, Baltacı 379). Bu analizde, veriler özetlenmiş ve yorumlanmış bir şekilde sunmaktadır (Özdemir 336). Katılımcıların cevapları 31 ayrı dosya olarak programa aktarılmıştır. Elde edilen veriler farklı temalar altında bir araya getirilecek şekilde kodlanmış ve sınıflandırılmıştır. Kodlamalar tümdengelimsel ve tümevarımsal yollarla oluşturulmuştur. Tümdengelimsel kodlama, alanyazında mevcut olan çalışmalar ve teorik çerçeve ile oluşturulmaktadır (Şen ve Öztekin 66). Tümevarımsal kodlama ise, katılımcılardan alınan verilere dayarak ilgili kategoriler ve temalar ortaya çıkarılmaktadır (Bümen ve Yazıcılar 196). Bu kodlar analiz edilmiş, görsel hale getirilmiş ve ardından sonuçlar çıkarılarak yorumlanmıştır.

Araştırmada kullanılan görüşme soruları aşağıda gösterilmiştir.

Sizce Türk Devletleri arasında;

1. Turizm alanında iş birliği Türk Dünyası ülkelerine katkı sağlar mı?

2. Eğer sağlayacağını düşünüyorsanız, Türk Dünyası ülkelerinde turizm alanında iş birliğinin sağlanmasına yönelik neler yapılabilir?

3. Ülkenizin turizmde kullanılan veya kullanılabilecek en önemli turistik değerleri nelerdir?

4. Türk Dünyasının ülkenizdeki ortak kültürel mirasları nelerdir? Bu miras değerleri gelecekte ilgili ülkeler arasında turizm hareketliliği sağlanmasına katkıda bulunabilir mi?

5. Ülkenizin turizmdeki performansını yeterli buluyor musunuz? Ülkeniz turizmde hangi konularda güçlü, hangi konularda zayıftır?

6. Türk Dünyası ülkelerinde bulunan turizm destinasyonlarının taraf ülkelerde tanıtımının ve pazarlamasının yapılması gerekiyor mu? Bu konuda neler yapılabilir?

7. Ülkenizdeki turistik destinasyonlarda;

- Seyahat acenteciliği,

- Türk Dünyası ülkelerinden gelecek turistlere yönelik ulaşım (havayolu, karayolu, demiryolu veya denizyolu),

- Konaklama,

- Yiyecek-içecek alt ve üst yapıları yeterli midir? 
8. Turizm eğitimi konusunda iş birliği yapılması gerekli midir? Bu konudaki görüşleriniz ve önerileriniz nelerdir?

9. Türk Devletleri arasında turizm iş birliğine yönelik bir çatı örgütün kurulması ilgili ülkelere katkı sağlar mı? Bu örgütün ne tür bir yapılanması ve ne tür görevleri olması gerekir?

10. Türk Dünyası ülkeleri arasında seyahatler nasıl kolaylaştırılabilir

Geçerlik ve Güvenirlik (Güven Duyulabilirlik)

Her bilimsel araştırman belirli bir seviyede geçerli ve güvenilir olması gerekmektedir. Nitel araştırmada geçerlik, "araçlar, süreçler ve verilerin uygunluğu” anlamına gelmektedir (Leung). Bu kapsamda; hazırlanan sorular için öncelikle biri akademisyen, biri sektör profesyoneli ve birisi de Turizm Bakanlığı veya eşdeğer kuruluş çalışanı olmak üzere üç uzmandan görüşler alınmış ve iç geçerlik sağlanarak soru formu şekillendirilmiştir. Bu uzmanlarla araştırma sürecinde zaman zaman bir araya gelinmiş ve görüşme kayıtları üzerinde değerlendirmeler yapılmıştır. Veri toplanmaya başlanmadan önce araştırmacılar, katılımcılardan elde edecekleri verilerin sadece araştırmada kullanılacağını ve üçüncü kişiler ile paylaşılmayacağını ifade ederek güven sağlamaya çalışmışlardır. Daha sonra her ülkeden birer toplamda altı kişi üzerinde pilot uygulama yapılmış ve araştırma ekibinin geribildirimleri değerlendirmesi neticesinde soru formuna son hali verilmiştir. Görüşme öncesinde veri toplanacak kişilerle bir ön görüşme yapılmış ve soru formu bu kimselerle önceden paylaşılmıştır. Belirlenen kişilere araştırmaya katılmaktan vazgeçme hakkı tanınarak gönüllü ve samimi cevaplar elde edilmeye çalışılmıştır. Çalışma sonuçlarının görüşme yapılan kişilerle paylaşılacağı da bildirilmiştir.

Görüşme esnasında zaman zaman aynı sorular farklı şekillerde sorularak verilerin doğruluğu test edilmiştir. Son olarak araştırmada çeşitlilik sağlamak adına tüm araştırmacılar veri toplama sürecine katılmış ve araştırmacıların elde ettiği sonuçlar süreç içerisinde kıyaslanarak yorumların gerçekçiliği arttırılmaya çalışılmışır. Bununla birlikte, araştırmanın alanında uzman ve nitel araştırma deneyimi olan beş araştırmacı tarafından gerçekleştirilmiş olması da inandırıcılığı destekleyen unsurlar arasındadır. Araştırmada Creswell (2009)'in önerdiği katılımcı kontrolü de gerçekleştirilmiş ve inandırıcılık düzeyi arttırılmaya çalışılmıştır. Bunun için görüntülü görüşme ka- 
yıtları sonrasında deşifre edilen ifadeler, görüşme yapılan kişilere e-posta yoluyla gönderilmiş ve uygun bulmadıkları kısımlar konusunda geribildirim sağlamaları talep edilmiştir. Azerbaycan ve KKTC katılımcıları ile yapılan görüşmelerde herhangi bir dil sorunu yaşanmamıştır. Özbekistan, Kazakistan ve Kırgızistan katılımcılarıyla, o ülke vatandaşı olup Türkiye Türkçe’sini bilen tercümanlar aracılığıyla görüşme yapılmıştır.

Nicel araştırmalardaki genellemenin yerine nitel araştırmalarda kullanılan aktarılabilirliğin sağlanması için Shenton (2004)'un önerdiği yöntem temel alınmıştır. Bu kapsamda, çalışma başlamadan önce hangi ülke, kişi veya kuruluşlardan veri toplanacağı, görüşme yapılacak kişi sayısı, görüşmelerin yapılacağı kişilerin sınırlılıkları, verilerin ne şekilde toplanacağı, her bir görüşmenin ne kadar zaman alacağı gibi konular karara bağlanmıştır. Kodlayıcıların güvenirliğini belirlemede Miles ve Huberman (1994)'ın önerdiği yöntem kullanılmıştır. Buna göre, iki farklı araştırmacının yaptığı kodlamalar arasındaki görüş birliği ve görüş farklılıkları hesaplanmış ve sonuçta araştırmanın güvenirliğinin \%86 olduğu ortaya çımıştır. Bu sonuç \%70’in üzerinde bir değer olduğu için araştırma verilerinin güvenilir olduğu görülmüştür.

\section{Bulgular}

Turizmin Türk Dünyasına Olası Katkılarına Yönelik Bulgular

Katılımcılara "Turizm alanında iş birliği Türk Dünyası ülkelerine katkı sağlar mı?” sorusu sorulmuş; verilen cevaplara göre bütün katılımcılar iş birliğinin büyük katkı sağlayacağı konusunda hem fikir olmuştur. Bazı katılımcılar, Türk devletleri arasında turizm sektörünü canlandırmak ve geliştirmek için iş birliği yapılmasının neden gerekli olduğuna değinmişlerdir. KKTC'den bir katılımcı (K28), KKTC’nin Türkiye Cumhuriyeti dışında hiçbir ülke tarafından tanınmamasını; diğer bir katılımcı (K29), KKTC'nin ambargo altında bir ülke olmasını neden olarak göstermişlerdir. Kırgızistan'dan iki katılımcı (K20, K22) turizmin birçok sektöre ekonomik ve sosyo-kültürel anlamda olumlu etkisi olan bir sektör olmasını ve Türk devletlerinin turizm anlamında büyük potansiyele sahip olmasını neden olarak belirtmişlerdir. Kazakistan'dan iki katılımcı (K18, K30), ülkede turistlerin bulunduğu destinasyonlarda hizmet kalitesinin düşük olması ve denetim sisteminin olmamasını; diğer bir katılımcı (K27) Türk devletlerinin kendi arasında ortak 
kültürel mirasın bulunmasını neden olarak göstermiştir. Azerbaycan'dan bir katılımcı (K13), Türk devletleri entegrasyonunun başarısının tüm Avrasya bölgesinde güvenlik ve istikrarı güçlendirmek için stratejik öneme sahip olmasını; Azerbaycan turizminin önündeki engellerini ve turizmde hizmet kalitesinin düşük olmasını neden olarak ileri sürmüştür.

Türk Dünyası Ülkelerinde İş Birliğinin Sağlanmasının Yollarına İlişkin Bulgular

Katılımcılara "Türk Dünyası ülkelerinde turizm alanında iş birliği sağlanmasına yönelik neler yapılabilir?" sorusu sorulduğunda elde edilen cevaplar Tablo 2'de gösterilmiştir.

\section{Tablo 2}

Türk Dünyası Ülkelerinde Turizm Alanında İş birliği Sağlanmasına Yönelik Öneriler

\section{Türk Dünyası Ülkelerinde Turizm Alanında İş Birliği Katılımcılar Sağlanmasına Yönelik Yapılması Gerekenler}

Türk devletlerine yönelik turizm sektöründe hizmet standartlarının oluşturulması

Yapılacak işbirliklerinin kâğıt üzerinde kalmayıp uygulamaya geçmesine dikkat edilmesi

Ortak iş birliğine başlanırken öncelikle tarafların yükümlülüklerinin ve haklarının belirlenmesi

Türk devletlerinde turizm uzmanlarının deneyim paylaşımlarının yapılması

Konaklama hizmetini veren ve yiyecek-içecek servisi yapan çalışanların eğitilmesi

Ulaşım ve hizmet kalitesini yükseltmek için projeler geliştirilmesi

Marka destinasyonların oluşturulmasına yönelik çalışmalar yapılması

Türk devletlerinde turizm sektöründe kalifiye personel yetiştirilmesi konusunda destek verilmesi

Kamu ile özel sektörün beraber çalışması

Türk devletleri arasındaki iş birliğini geliştirmek için Büyük İpek Yolu tur paketi gibi çeşitli tur paketlerinin düzenlenmesi Ortak projelerin yapılması
$\mathrm{K} 18, \mathrm{~K} 30, \mathrm{~K} 7$, K20

K7

K18

K17, K10

K30, K20

K22

K20

K20, K12, K8, K1, K24

K25, K10

K7

K12 
Türk dünyası ülkelerinin ortak markalarının oluşturulması

Türk dünyası ülkelerindeki turistik destinasyonların potansiyellerinin ortaya çıkarılması

Türk Dünyası ülkelerinde acentaların çoğaltılması, gerekli tanıtımın yapılması, algının doğru yönlendirilmesi, acentelere teşviklerin yapılması, başta ulaşım olmak üzere turizm hizmet fiyatlarının optimize edilmesi

Turizm altyapısının kalitesinin yükseltilmesi

Yapılacak işbirliklerinde üniversitelerin turizm bölümlerinin de yer almasi

Türk devletlerinden gelen turistlere indirim sağlanması

İşbirliklerine yönelik Türk devletlerinden temsilci üyelerin birbirleriyle belli dönemlerde toplantılar yapması

Göçebe oyunları organizasyonu, müzik festivalleri, halk oyunları yarışmaları, şiir okuma yarışması, arkeoloji ve tarih araştırmacıları için çevrim içi seminerler, bilimsel tematik geziler/turlar, yemek festivallerinin organizasyonu (örneğin kebap yarışması) gibi aktiviteler konusunda işbirliklerinin yapilması

Yapılacak iş birliği kapsamında Türkiye'nin turizm sektöründe sahip olduğu tecrübeyi Türk devletlerine aktarıp turizmde hem özel sektörde hem kamu kurumlarında kurumsallaşma düzeylerinin arttırılmasına katkı sağlanması Türk devletlerinin ortak turizm ürünleri geliştirmesi

Yapılacak işbirliklerinin Türk kültürünü tanıtıcı özelliğe sahip K2 olması

Yapılacak işbirlikleriyle daha çok turist çekmenin amaçlanması
$\mathrm{K} 13, \mathrm{~K} 3$

K11

K14, K18

K13

K16

K10, K9, K18

K19

K5

K23

Tablo 2'de görüldüğü üzere katılımcılar çoğunlukla; hizmet standartlarının oluşturulması, kalifiye personel yetiştirilmesi, kamu ve özel sektörün iş birliği, turizm altyapısının iyileştirilmesi, Türk devletlerinden temsilcilerin periyodik olarak toplantılar yapması, turizm uzmanlarının deneyim alışverişi yapması konusunda öneriler vermişlerdir. Kırgızistan'dan bir katılımc1 (K20), kalifiye personel eksikliğini gidermek için "Türkiye gibi turizm konusunda lider olan ülkelerden destek sağlanmalıdır” sözüyle, Türkiye’ yi sektör çalışanlarına eğitimler veren yönlendirici bir ülke konumunda görmüştür. Türkiye'den bir katılımcı (K2), yapılacak işbirliklerinin Türk kültürünü tanıtıcı özelliğe sahip olması gerektiğini, “Örneğin, Nevruz Bayramı 
gibi gerçekten kökü kültürümüzde olan bayramlar bir yıl Türkiyede kutlanırken, bir yıl Özbekistan'da diğer yıl Kazakisan'da kutlanabilir. Bu gibi ortak büyük etkinlikler yapılabilir” sözüyle ifade etmiştir.

Türk Dünyası Ülkelerinde Turizmde Kullanılan veya Kullanılabilecek En Önemli Turistik Değerlere Yönelik Bulgular

Katılımcılara "Ülkenizin turizmde kullanılan veya kullanılabilecek en önemli turistik değerleri nelerdir?” sorulduğunda elde edilen cevaplar Tablo 3 'te gösterilmiştir.

\section{Tablo 3}

Türk Devletlerinde Turizmde Kullanılan veya Kullanılabilecek En Önemli Turistik Değerler

\begin{tabular}{ll}
\hline Turistik Değerler & Katılımcılar \\
\hline Sağlık turizmi & $\mathrm{K} 16, \mathrm{~K} 15, \mathrm{~K} 12, \mathrm{~K} 13, \mathrm{~K} 22, \mathrm{~K} 20$ \\
Kış turizmi & $\mathrm{K} 15, \mathrm{~K} 13$ \\
Tarihi, kültürel ve inanç miras & $\mathrm{K} 11, \mathrm{~K} 13, \mathrm{~K} 10, \mathrm{~K} 9, \mathrm{~K} 8, \mathrm{~K} 19, \mathrm{~K} 16, \mathrm{~K} 28, \mathrm{~K} 31$, \\
değerleri/İnanç turizmi & $\mathrm{K} 21, \mathrm{~K} 18, \mathrm{~K} 30, \mathrm{~K} 2, \mathrm{~K} 24, \mathrm{~K} 1$ \\
Doğal güzellikler & $\mathrm{K} 14, \mathrm{~K} 13, \mathrm{~K} 19, \mathrm{~K} 6, \mathrm{~K} 28, \mathrm{~K} 26, \mathrm{~K} 7, \mathrm{~K} 25, \mathrm{~K} 4$, \\
& $\mathrm{K} 18, \mathrm{~K} 27, \mathrm{~K} 30, \mathrm{~K} 4, \mathrm{~K} 5$ \\
Gastronomi turizmi & $\mathrm{K} 12, \mathrm{~K} 13, \mathrm{~K} 10, \mathrm{~K} 6, \mathrm{~K} 28, \mathrm{~K} 29, \mathrm{~K} 22, \mathrm{~K} 25, \mathrm{~K} 7$ \\
Misafirperverlik & $\mathrm{K} 13, \mathrm{~K} 6$ \\
Kumar turizmi & $\mathrm{K} 29, \mathrm{~K} 31$ \\
Eğitim turizmi & $\mathrm{K} 31$ \\
Deniz-kum-güneş turizmi & $\mathrm{K} 31, \mathrm{~K} 3, \mathrm{~K} 2, \mathrm{~K} 24$ \\
İpek Yolu & $\mathrm{K} 22, \mathrm{~K} 26, \mathrm{~K} 30$ \\
Ekoturizm & $\mathrm{K} 25, \mathrm{~K} 13, \mathrm{~K} 18$ \\
Kitle turizmi & $\mathrm{K} 1$ \\
\hline
\end{tabular}

Tablo 3'e göre, 15 katılımcı tarihi, kültürel ve inanç mirasları, 14 katılımcı doğal güzellikleri, 9 katılımcı gastronomi turizmini, 2 katılımcı misafirperverliği, 2 katılımc1, kumar turizmini, bir katılımcı eğitim turizmini, 4 katılımcı deniz-kum-güneş turizmini, 3 katılımcı İpek Yolu’nu, 3 katılımcı ekoturizmi, ve 1 katılımcı ise kitle turizmini turistik değer olarak göstermiştir. 
Türk Dünyası Ülkelerindeki Ortak Kültürel Miraslara Yönelik Bulgular

Katılımcıların hepsi ortak kültürel miras değerlerinin gelecekte ilgili ülkeler arasında turizm hareketliliği sağlanmasına katkıda bulunacağı konusunda hem fikir olmuştur. Katılımcılara "Türk Dünyasının ülkenizdeki ortak kültürel mirasları nelerdir?” sorusu sorulduğunda elde edilen cevaplar Tablo 4’te gösterilmiştir.

\section{Tablo 4}

Türk Devletlerinde Türk Dünyasına Özgü Ortak Kültürel Miraslar

\begin{tabular}{ll}
\hline Ortak Kültürel Miraslar & Katılımcılar \\
\hline Ortak gelenek ve görenekler & K11, K16, K25, K21, K18, K24 \\
Ortak yemekler & K11, K16, K19, K28, K22 \\
Ortak edebi eserler & K11 \\
İpek Yolu & K11, K5 \\
Tarihi yapılar & K15, K10, K9, K8, K19, K29, K31, K25, \\
& K21, K22, K25, K20, K26, K17, K27, K3 \\
Ortak dini değerler & K11, K9, K6 \\
Müzik türleri ve edebiyat & K19 \\
Danslar ve şarkılar & K22 \\
K1l çadırlar & K22 \\
Hıdırellez Bayramı & K17 \\
Nevruz Bayramı & K30, K2 \\
$\begin{array}{l}\text { Ortak kültür sporları (Türk } \\
\text { okçuluğu, güreş ve at binme) }\end{array}$ & K2 \\
$\begin{array}{l}\text { Destanlar (Köroğlu, Manas, Dede } \\
\text { korkut) }\end{array}$ & K11, K13 \\
\hline
\end{tabular}

Tablo 4'e göre, 6 katılımcı gelenek ve görenekleri, 5 katılımcı, ortak yemekleri, 1 katılımcı edebi eserleri, 16 katılımcı tarihi yapıları, 3 katılımcı ortak dini değerleri, 1 katılımcı ortak danslar ve şarkıları, 1 katılımcı kıl çadırları, 1 katılımcı Hıdırellez Bayramı'nı, 2 katılımcı Nevruz Bayramı'nı, 1 katılımcı ortak kültür sporlarını, 2 katılımcı ortak destanları Türk devletlerinin sahip olduğu ortak kültürel miraslar olarak değerlendirmiştir.

Türk Dünyası Ülkelerindeki Turizm Performans Algısına İlişkin Bulgular Katılımclara "Ülkenizin turizmdeki performansını yeterli buluyor musunuz?” sorusu sorulduğunda elde edilen cevaplar Tablo 5 'te gösterilmiştir. 


\section{Tablo 5}

Katılımcıların Ülkelerinin Turizm Performansı Hakkındaki Görüşleri

\begin{tabular}{ll}
\hline Yeterli (7 kişi) & K3, K5, K1, K4, K17, K27, K30 \\
Kısmen Yeterli (6 kişi) & K15, K14, K12, K13, K24, K8 \\
Yetersiz (18 kişi) & K2, K23, K28, K29, K31, K6, K16, K11, K18, \\
& K21, K22, K25, K7, K20, K26, K9, K10, K19 \\
\hline
\end{tabular}

Tablo 5 ve Şekil 1'e göre, katılımcıların \%58,1'i (18 kişi) ülkelerindeki turizm performansını yeterli bulmadığını; katılımcıların \%22,6'sı (7 kişi) ülkelerindeki turizm performansını yeterli bulduğunu ve \% 19,4’ü (16 kişi) ülkelerindeki turizm performansının kısmen yeterli olduğunu belirtmiştir.

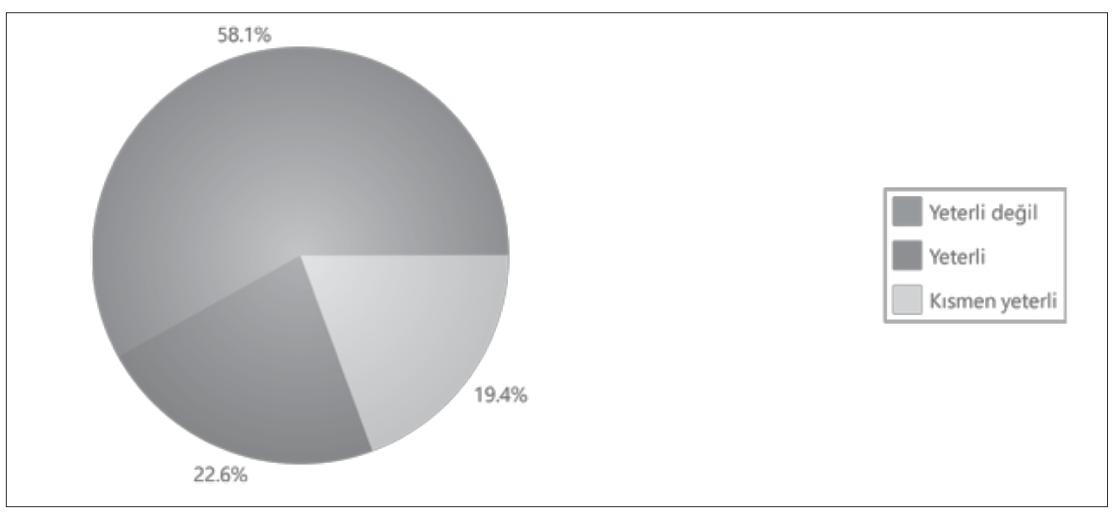

Şekil 1. Katılımcıların Ülkelerinin Turizm Performansı Hakkındaki Görüşlerinin Yüzdeleri

Şekil 2'ye göre, ülkelerinin turizmdeki performansını yetersiz gördüklerini belirten katılımcıların çoğunluğu Özbekistan, KKTC ve Kırgızistan'dan katılan katılımcılardır. Türkiye ve Kazakistan katılımcıları ise ülkelerinin turizmdeki performansını yeterli görmektedirler. Azerbaycan'daki katılımc1ların çoğu ülkelerinin turizmdeki performansını kısmen yeterli bulduklarını belirtmişlerdir. 


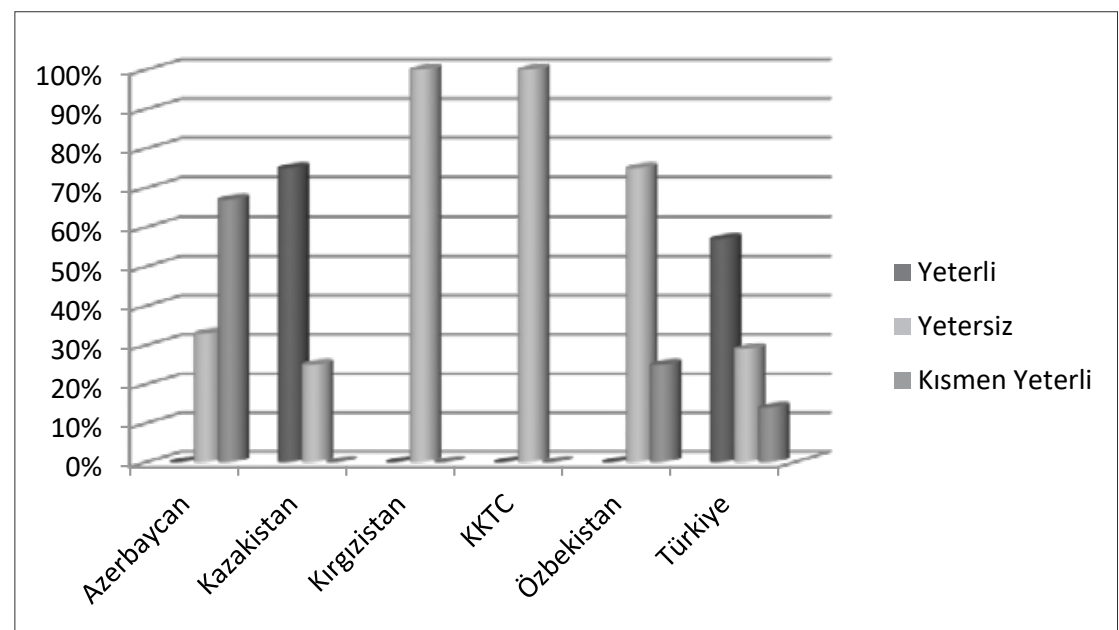

Şekil 2. Turizm Performansı Hakkındaki Görüşlerin Ülkelere Göre Dağılımı

Türk Dünyası Ülkelerindeki Turistik Destinasyonlardaki Yeterliliklere İlişkin Bulgular

Katılımcıların "Ülkenizdeki turistik destinasyonlarda seyahat acenteciliği; Türk Dünyası ülkelerinden gelecek turistlere yönelik ulaşım (havayolu, karayolu, demiryolu veya denizyolu); konaklama, yiyecek-içecek alt ve üst yapıları yeterli midir?” sorusuna verdiği cevaplar Şekil 3’te gösterilmiştir.

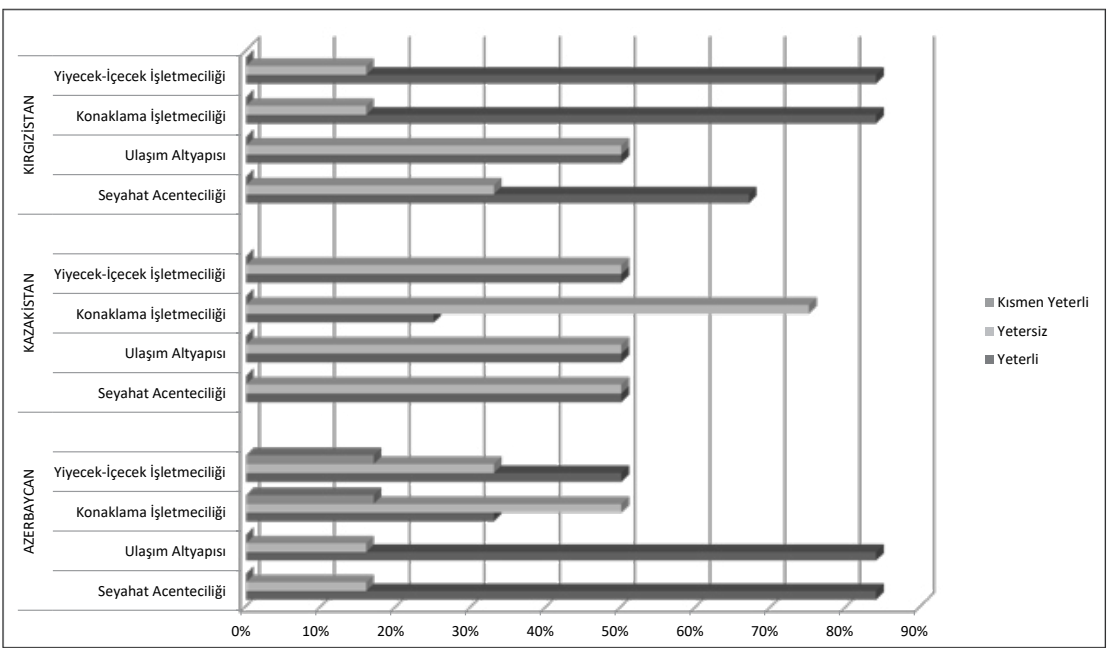




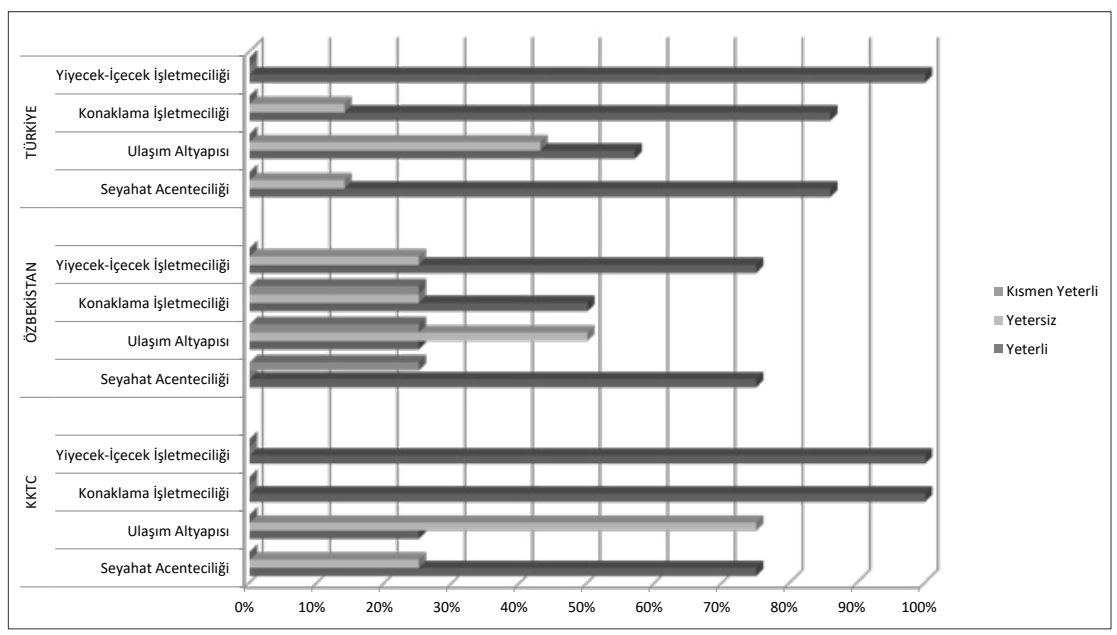

Şekil 3. Katılımcıların "Ülkenizdeki turistik destinasyonlarda seyahat acenteciliği, Türk dünyası ülkelerinden gelecek turistlere yönelik ulaşım, konaklama, yiyecek-içecek alt ve üst yapıları yeterli midir?” Sorusuna Verdiği Cevapların Yüzde (\%) Şeklinde Gösterimi

Şekil 3’e göre, Kazakistan' daki katılımcıların çoğunluğu konaklama işletmeciliği, yiyecek-içecek işletmeciliği ve seyahat acenteciliğinin yeterli olduğunu belirtmiş ve ulaşım altyapısının yeterli olup olmadığı konusunda fikir birliği sağlayamamıştır. Kırgızistan’ daki katılımcıların çoğunluğu yiyecek-içecek işletmeciliği, seyahat acenteciliği ve ulaşım altyapısının yeterli olup olmadığı konusunda fikir birliğine varamamış ve konaklama işletmeciliğinin yetersiz olduğunu belirtmiştir. Azerbaycan'daki katılımcıların çoğunluğu yiyecek-içecek işletmeciliği, seyahat acenteciliğinin ve ulaşım altyapısının yeterli olduğunu; ama konaklama işletmeciliğinin yetersiz olduğunu belirtmişlerdir. Türkiye' deki katılımcıların çoğunluğu bütün alt ve üst yapıların yeterli olduğu konusunda hem fikir olmuşlardır. Özbekistan' daki katılımcıların çoğunluğu yiyecek-içecek işletmeciliği, seyahat acenteciliği ve konaklama işletmeciliğinin yeterli ama ulaşım altyapısının yetersiz olduğunu ifade etmişlerdir. KKTC' deki katılımcıların çoğunluğu yiyecek-içecek işletmeciliği, seyahat acenteciliği ve konaklama işletmeciliğinin yeterli olduğunu belirtirken ulaşım altyapısının yetersiz olduğunu belirtmişlerdir. 
Türk Dünyası Ülkelerinin Turizmde Güçlü ve Zayıf Yönlerine İlişkin Bulgular

Katılımcıların "ülkeniz turizmde hangi konularda güçlü, hangi konularda zayıftır?” sorusuna verdiği cevaplar Tablo 6’da gösterilmiştir.

\section{Tablo 6}

Türk Devletlerinin Turizm Sektöründeki Güçlü ve Zayıf Yönlerinin Analizi

\begin{tabular}{lll}
\hline & \multicolumn{1}{c}{ Katılımc1lar } \\
\hline Tarihi ve kültürel değerler & K18, K17, K27, K4, K7, \\
& & K20, K25, K4, K24, \\
& & K10, K13, K9, K19, \\
& Kisafirperverlik & K25, K26, K15, K14 \\
Coğrafi konum ve iklim & K29, K30, K3, K13 \\
Turizmi geliştirebilecek potansiyel kaynaklar & K21, K30, K22, K12 \\
Doğal güzellikler & K18, K17, K27, K4, K7, \\
& K20, K25, K4, K23, K9 \\
Gastronomi turizmi & K28, K23, K19, K15 \\
Täraflar dünyası ülkelerinde bazı destinasyonlar arasında düzenli & K29 \\
uçus olması & K6, K28, K2, K1, K5 \\
Kitle turizmi & K6, K28 \\
Acentelerin ve otellerin kaliteli olmas1 & K31 \\
Eğitim turizmi & K25, K26 \\
Gelenek ve görenekler & K30, K13 \\
İpek Yolu & K2 \\
Türk Hava Yolları & K2, K1, K3 \\
Kalite-fiyat dengesinin iyi olması & K6, K4,K5 \\
Gelen turist sayısının fazla olması &
\end{tabular}


Turizm işletmelerinin belli merkezlerde toplanmış olması

Kalifiye personel yetersizliği

1-2-3 yıldızlı otellerin bulunmaması

4 ve 5 yıldızlı otel fiyatlarının çok yüksek olması
K13, K15

K11, K12, K13, K19, K9, K8,

K21, K26, K25, K17, K30

K12, K13

Deniz-kum-güneş hizmeti veren turizm işletmelerinin nicelik ve nitelik olarak yetersizliği

Turizm tanıtımlarının yetersizliği

Turizm tesisi yatırımlarındaki maliyetlerin yüksekliği

Turizm sektörünün analizini yapabilecek istatistiksel veri tabanı eksikliği

Gelen yabancı turistlerin memnuniyet düzeyini ölçmedeki eksiklik K11, K13, K20, K17, K30, $\mathrm{K} 3, \mathrm{~K} 24$

$\mathrm{K} 11$

K13

Deniz kenarlarının temizliği ve çevrenin korunmasına yönelik yetersizlikler

Turizm eğitiminin yetersizliği

Turizm sektöründe tecrübe eksikliği

Turizm sektörü için yeterli düzeyde uluslararası standartlara uygun yapıların olmaması (üstyapı eksikliği)

Zayıf Uluslararası uçuş sayısının yetersizliği

Taraflar Uçak bilet ve otel fiyatlarının çok yüksek olması

Turizm sektöründeki finansman ve altyapı yetersizliği

Ülkeye Türkiye dışında başka hiç bir ülkeden direk uçuşun olmaması

K12, K13

K12, K19, K9, K8, K17, K30

K19, K9, K8

K10

K9, K26, K7

K8

K13, K21, K26, K7, K27, $\mathrm{K} 30$

Kuzey Kıbrıs Türk Cumhuriyeti'ni Türkiye dışında başka hiç bir ülkenin tanınmaması

Kitle turizmi

K6, K31

Gelen turistlerin geceleme sayılarının az olması

Turist çekimindeki yetersizlik

K20

Hizmet kalitesinin düşük olması

$\mathrm{K} 13, \mathrm{~K} 27, \mathrm{~K} 31, \mathrm{~K} 29$

K21, K26, K25, K18, K17

Yol kenarlarında bulunan dinlenme tesislerindeki hijyen ve hizmet kalitesinin yetersizliği

Ulaşım imkânlarının yetersizliği

Turistik bölgelerde yaşayan insanların turistleri

kabullenebilmesindeki yetersizlikler

K18, K17

K13, K26, K7, K27, K30

K2

Terör olayları - Siyasi sorunlar

Kitle turzimine verilen önemin alternatif turizm türlerine yeteri kadar verilmemesi

K14, K3, K1

K24, K23, K16

Değişen turist profili ve değişen turizm trendleri karşısında ürün geliştirme ve marka geliştirme noktasında istenilen 
Tablo 6'ya göre katılımcılar çoğunlukla, tarihi ve kültürel değerleri, misafirperverliği, coğrafi konum ve iklimi, turizmi geliştirebilecek potansiyel kaynakları, doğal güzellikleri, gastronomi turizmini ve kitle turizmini ülkelerinin turizmde güçlü yönleri olarak değerlendirmişlerdir. Ülkelerin turizmde zayıf yönleri ise çoğunlukla, kalifiye personel yetersizliği, turizm tanıtımlarının yetersizliği, turizm eğitiminin yetersizliği, turizm sektöründeki finansman ve altyapı yetersizliği, turist çekimindeki yetersizlik, hizmet kalitesinin düşük olması ve ulaşım imkânlarının yetersizliği olarak ifade edilmiştir.

Katılımcılar Türk dünyası ülkelerinde bulunan turizm destinasyonlarının taraf ülkelerde tanıtımının ve pazarlamasının yapılması gerektiği konusunda hem fikir olmuşlardır.

Türk Dünyası Ülkelerindeki Turizm Destinasyonlarının Taraf Ülkelerde Tanıtım ve Pazarlamasına İlişkin Bulgular

Katılımcıların "Türk Dünyası ülkelerinde bulunan turizm destinasyonlarının taraf ülkelerde tanıtım ve pazarlaması için neler yapılabilir?” sorusuna verdiği cevaplar Tablo 7'de verilmiştir.

\section{Tablo 7}

Türk Dünyası Ülkelerinde Bulunan Turizm Destinasyonlarının Taraf Ülkelerde Tanıtım ve Pazarlaması için Yapılması Gerekenler

\begin{tabular}{ll}
\hline Tanıtım ve Pazarlama için Neler Yapılabilir? & Katılımcılar \\
\hline $\begin{array}{l}\text { Türk Devletlerinde faaliyet gösteren tur } \\
\text { şirketlerinin birbirleriyle iş birliği yaparak, bu }\end{array}$ & $\mathrm{K} 17, \mathrm{~K} 26, \mathrm{~K} 7$ \\
ülkelere yönelik bilgilendirme turları düzenlenmesi & \\
$\begin{array}{l}\text { Turistlerde güven ve turizm bilincinin oluşması } \\
\text { için Türklerin doğudan batıya doğru sürdürmüş̧ }\end{array}$ & $\mathrm{K} 2, \mathrm{~K} 28, \mathrm{~K} 12, \mathrm{~K} 11, \mathrm{~K} 13, \mathrm{~K} 18, \mathrm{~K} 30, \mathrm{~K} 17$, \\
oldukları 1500 yıllık macerayı, Türk Dünyası & \\
ülkelerinin ortak kültürel miraslarının ve & \\
destinasyonları farklılaştıran diğer turistik & \\
cazibelerinin reklam kampanyaları ile tanıtılması & \\
(Bu reklam kampanyalarının Türk devletlerinin & \\
tam katılımıyla gerçekleşmesi önerilmektedir. & \\
$\begin{array}{l}\text { Ayrıca, bu reklamların ülkelerdeki tanınmış } \\
\text { televizyon kanallarında, reklam panolarında } \\
\text { gösterilmesi önerilmektedir) }\end{array}$
\end{tabular}


Tanıtım ve pazarlama çalışmalarının dijital olarak yapilması

Sanal gerçeklik teknolojisi ile turların düzenlenmesi, bu yolla turistlerin bu ülkelerdeki turizm ürünlerini önce oturdukları yerden deneyimlemeleri, daha sonra oralara seyahat etme ve gerçekte de deneyimleme isteklerinin oluşturulması

Sosyal medya üzerinden paylaşılacak ortak bir video projesinin hayata geçirilmesi

Eğitim turizminin geliştirilmesi için çalışmaların yapilması

Türk Devletleri arasında periyodik olarak kongre, sergi ve fuar gibi etkinliklerin düzenlenmesi

Türk Devletlerinde faaliyette bulunan acentelere teşvikler sunulması

Türk Devletlerinde turistler için daha fazla güvenlik tedbirlerinin alınması ve desinasyonların turistler için güvenli olduğuna yönelik tanıtımlar yapilması

Türk Devletlerinin ortak bir televizyon kanalına sahip olması

Türk devletleri için ortak bir slogan geliştirilip kullanılması

Türk Devletleri arasında ortak bir seyahat acentesi oluşturulup, tanıtımların ortak yapılması
K24, K11, K22, K26, K20, K12, K13, K31

K31

K12

K24, K25, K13

K13, K6, K16, K26, K9, K20, K12, K13, K4, K17, K11

K6, K11

K24, K8

K11

K13

K22

Tablo 7’ye göre, katılımcılar çoğunlukla turistlerde güvenin ve turizm bilincinin oluşması için Türklerin doğudan batıya doğru sürdürmüş oldukları 1500 yıllık macerayı, Türk Dünyası ülkelerinin ortak kültürel miraslarının ve destinasyonları farklılaştıran diğer turistik cazibelerinin reklam kampanyaları ile tanıtılması; tanıtım ve pazarlama çalışmalarının dijital olarak yapılması, Türk Devletleri arasında periyodik olarak kongre, sergi ve fuar gibi etkinliklerin düzenlenmesini Türk Devletlerinde turizmin tanıtım ve pazarlamasının iyileştirilmesi için önermiştir. 
Türk Dünyası Ülkelerindeki Turizm Eğitiminde İşbirliğine İlişkin Bulgular

Katılımcıların hepsi turizm eğitiminde iş birliği yapılması gerektiği konusunda ortak görüş bildirmişlerdir. Bu konuda katılımcıların görüşleri ve önerileri Tablo 8'de belirtilmiştir.

\section{Tablo 8}

Turizm Eğitiminde İşbirliğine Yönelik Öneriler

\begin{tabular}{|c|c|}
\hline $\begin{array}{l}\text { Turizm Eğitiminde İşbirliğine Yönelik } \\
\text { Öneriler }\end{array}$ & Katılımcilar \\
\hline $\begin{array}{l}\text { Öğrenci ve akademik personel değişim } \\
\text { programlarının daha çok desteklenmesi }\end{array}$ & $\begin{array}{l}\text { K3, K2, K16, K15, K10, } \\
\mathrm{K} 11, \mathrm{~K} 18, \mathrm{~K} 17, \mathrm{~K} 21, \mathrm{~K} 9, \\
\mathrm{~K} 27, \mathrm{~K} 14, \mathrm{~K} 28, \mathrm{~K} 20, \mathrm{~K} 19, \\
\mathrm{~K} 25, \mathrm{~K} 13, \mathrm{~K} 12, \mathrm{~K} 30, \mathrm{~K} 31\end{array}$ \\
\hline Üniversiteler arası diplomaların tanınması & K16 \\
\hline $\begin{array}{l}\text { Türk Devletlerindeki üniversitelerin turizm } \\
\text { bölümlerinde Türk Dünyası ülkeleri arası } \\
\text { öğrenci ve akademik personel değişimlerini } \\
\text { yöneten bir merkezi kurumun kurulması }\end{array}$ & K16 \\
\hline $\begin{array}{l}\text { Bu ülkelerde turizm eğitimi veren üniversiteler } \\
\text { arasında çevrimiçi sistemde kısa eğitim } \\
\text { programları ve değişim kurslarının uygulanması }\end{array}$ & $\mathrm{K} 18, \mathrm{~K} 22$ \\
\hline $\begin{array}{l}\text { Öğrenci stajlarının Türk Dünyası ülkelerinde } \\
\text { yapılmasına destek verilmesi }\end{array}$ & K28, K13 \\
\hline $\begin{array}{l}\text { Bu ülkelerde turizm eğitimi veren üniversitelerde } \\
\text { müfredat birliğinin sağlanması ve bu ortak } \\
\text { müfredatın sektör-akademi iş birliğinde } \\
\text { oluşturulması }\end{array}$ & K28, K1, K12, K22, K20 \\
\hline $\begin{array}{l}\text { Uzmanların deneyim ve tecrübelerini aktarmak } \\
\text { için özel sektörde değişim programlarının } \\
\text { yapılması (Özellikle garsonlar, şoförler, } \\
\text { temizlikçiler, rehberler, resepsiyonistler gibi } \\
\text { hizmet personeli için bir değişim programı } \\
\text { oluşturulması) }\end{array}$ & $\begin{array}{l}\text { K12, K31, K17, K7, K21, } \\
\text { K14 }\end{array}$ \\
\hline $\begin{array}{l}\text { Türk Devletlerinin ortak bir turizm } \\
\text { üniversitesinin olması }\end{array}$ & K11 \\
\hline $\begin{array}{l}\text { Türk Devletlerinde turizm eğitiminin gelişmesi } \\
\text { için Türkiye'nin öncü olması }\end{array}$ & $\mathrm{K} 24, \mathrm{~K} 2$ \\
\hline
\end{tabular}


Şekil 4'te gösterildiği gibi ortak turizm eğitimi konusunda katılımcıların \%83,9'u, öğrenci ve akademik personel değişim programlarının daha çok desteklenmesini; katılımcıların \%22,6's1, bu ülkelerde turizm eğitimi veren üniversitelerde müfredat birliğinin sağlanması ve bu ortak müfredatın sektör-akademi iş birliğinde oluşturulmasını; katılımcıların \% 19,4’ü, uzmanların deneyim ve tecrübelerini aktarmak için özel sektörde değişim programlarının yapılmasını önermişlerdir.

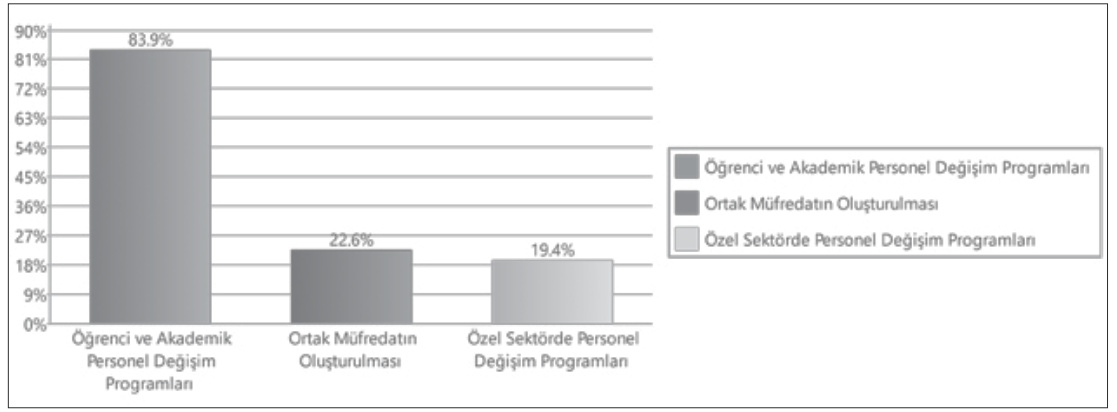

Şekil 4. Turizm Eğitiminde İşbirliğine Yönelik Ana Öneriler

Türk Dünyası Ülkeleri Arasında Turizm İşbirliğine Yönelik Bir Çatı Örgütün Kurulmasına Yönelik Bulgular

Türk Devletleri arasında turizm iş birliğine yönelik bir çatı örgütün kurulması ilgili ülkelere katkı sağlayacağına katılımcıların \%90,3'ü evet, \%6,5’i hayır ve \%3,2'si emin değilim cevabını vermiştir. Bu yüzdeler Şekil 5'te gösterilmiştir.

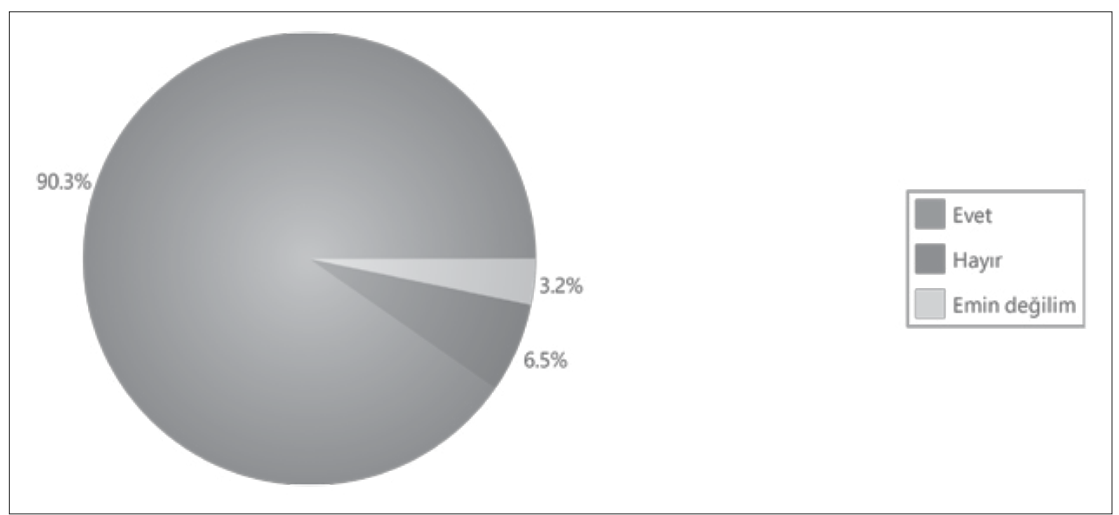

Şekil 5. "Türk Devletleri arasında turizm iş birliğine yönelik bir çatı örgütün kurulması ilgili ülkelere katkı sağlar mı”? Sorusuna Verilen Cevaplar 
Katılımcılar tarafından önerilen çatı örgüt için örnek alınması gereken birlikler ve çatı örgütte yer alması gereken kişiler/kurumlar Tablo 9'da gösterilmiştir.

\section{Tablo 9}

Çatı Örgüt için Örnek Alınacak Birlikler ve Çatı Örgütü Oluşturacak Kişi ve Kurumlar

\begin{tabular}{ll}
\hline Çatı Örgüt için Örnek Alınacak Birlikler & Katılımcılar \\
\hline Dünya Turizm Örgütü & K12, K25, K28 \\
TÜRKSOY & K11, K5, K24 \\
$\begin{array}{l}\text { Türk Konseyi } \\
\text { Evrensel Seyahat Acenteleri Dernekleri }\end{array}$ & $\mathrm{K} 5, \mathrm{~K} 13$ \\
$\begin{array}{l}\text { Federasyonu (Universal Federation of Travel } \\
\text { Agents Associations-UFTAA) }\end{array}$ & \\
$\begin{array}{l}\text { Avrupa Birliği } \\
\text { Çatı Örgütü Oluşturacak Kişi ve } \\
\text { Kurumlar }\end{array}$ & $\mathrm{K} 24$ \\
\hline $\begin{array}{l}\text { Turizm Bakanlı̆ından Temsilciler } \\
\text { Acente Birlikleri ve Otelciler Birlikleri }\end{array}$ & $\mathrm{K} 15, \mathrm{~K} 13, \mathrm{~K} 6, \mathrm{~K} 15, \mathrm{~K} 6, \mathrm{~K} 20, \mathrm{~K} 19, \mathrm{~K} 4$, \\
& $\mathrm{K} 1, \mathrm{~K} 3$ \\
$\begin{array}{l}\text { Turizm ve İlgili Alanlardan Akademisyenler } \\
\text { Konsolosluklardan Temsilciler }\end{array}$ & $\mathrm{K} 4, \mathrm{~K} 6, \mathrm{~K} 11, \mathrm{~K} 19$ \\
\hline
\end{tabular}

Tablo 9'a göre, üç katılımcı (K12, K25, K28) kurulacak çatı örgüt için Dünya Turizm Örgütünün örnek alınması gerektiğini belirtmiştir. Yapılanmasının ve görevlerinin benzer olması gerektiği önerilmiştir. Diğer üç katılımcı (K11, K5, K24) kurulacak çatı örgütün TÜRKSOY’u örnek alması gerektiğini ifade etmiştir. İki katılımcı (K5, K13) çatı örgütü kurarken Türk Konseyi'nin örnek alınıp incelenmesi gerektiğini belirtmiştir. Bu katılımcılardan bir tanesi Türk Konseyi'nin istenilen başarıyı elde edemediğine ve bunun sebeplerine dikkat edilmesi gerektiğini ifade etmiştir. Katılımcı "Saha da görev yapan örneklere bakarak nasıl verimli ve sürdürülebilir bir örgüt kurulması gerektiği üzerinde titizlikle çalışılması gerekiyor ve çok iyi koordine edilmesi gerekiyor. Aksi takdirde, geçmişte yaşadığımız başarısız örneklerden biri olur." sözleriyle bu konuda planlı bir şekilde çalışmak gerektiğini belirtmiştir. Bir katılımcı (K1) Evrensel Seyahat Acenteleri Dernekleri Federasyonu’ 
nun (Universal Federation of Travel Agents Associations-UFTAA) örnek alınması gerektiğini ifade etmiştir. Bu federasyonun, üyelerinin problemleri ile ilgilenip çözüme ulaştırmaya çalıştığını ifade etmiştir.

Diğer bir katılımcı (K24) Avrupa Birliği'ni kurulacak çatı örgüt için örnek alınacak bir yapı olarak değerlendirmiştir. Çatı örgütün altında AB'nde olduğu gibi çeşitli konseylerin olması gerektiğini ifade etmiştir.

İki katılımcı (K15, K6, K13) çatı örgütün içinde ülkelerin turizm bakanlıklarından temsilcilerin olması gerektiğini belirtmiştir. Yedi katılımcı (K13, K15, K6, K20, K19, K4, K1, K3) acente birlikleri ve otelci birlikleri gibi sektör temsilcilerinin çatı örgüte üye olması gerektiğini ifade etmiştir. Dört katılımcı (K4, K6, K1 1, K19) turizm akademisyenlerinin de bu örgütte yer alması gerektiğini belirtmiştir. Diğer bir katılımcı Türk Devletlerinin konsolosluklarının da bu örgüte dâhil olmasının yararlı olacağını belirtmiştir.

Katılımcıların "Bu örgütün ne tür bir yapılanması ve ne tür görevleri olması gerekir?” sorusuna verdiği cevaplar Tablo 10'da göstermiştir.

\section{Tablo 10}

Çatı Örgüt için Önerilen Görevler

\begin{tabular}{|c|c|}
\hline Çatı Örgütün Görevleri & Katılımcılar \\
\hline $\begin{array}{l}\text { Türk Devletlerinin turizm sektöründe bulunan } \\
\text { birimlerini ve kurumlarını bir araya getirmek, } \\
\text { ülkeler arası koordinasyon ve iletişimi sağlamak }\end{array}$ & $\mathrm{K} 13, \mathrm{~K} 14, \mathrm{~K} 16, \mathrm{~K} 31, \mathrm{~K} 9$ \\
\hline $\begin{array}{l}\text { Türk devletleri arasında turizm sektörü için ortak } \\
\text { bir plan ve projeler oluşturmak }\end{array}$ & K13, K16, K30, K31, K22 \\
\hline $\begin{array}{l}\text { Türk halklarının ortak değerleri olan kültürel ve } \\
\text { manevi miraslarını uluslararası seviyede tanıtmak } \\
\text { ve kaynakların birleştirilip ülkelerin turistik } \\
\text { değerlerinin tanıtımı ve pazarlamasını yapmak }\end{array}$ & $\begin{array}{l}\mathrm{K} 13, \mathrm{~K} 11, \mathrm{~K} 18, \mathrm{~K} 31, \mathrm{~K} 22, \\
\mathrm{~K} 9, \mathrm{~K} 8, \mathrm{~K} 19, \mathrm{~K} 5\end{array}$ \\
\hline $\begin{array}{l}\text { Türk Devletlerinin turizm sektöründe yaşadıkları } \\
\text { problemleri ve eksiklikleri (altyapı yetersizlikleri, } \\
\text { nitelikli personel yetersizliği vb.) belirlemek ve } \\
\text { bunlara çözüm önerleri sunmak }\end{array}$ & $\mathrm{K} 13, \mathrm{~K} 16$ \\
\hline $\begin{array}{l}\text { Türk Devletlerinin birbirleri arasında turist akışını } \\
\text { arttırmak }\end{array}$ & $\mathrm{K} 13, \mathrm{~K} 14, \mathrm{~K} 11, \mathrm{~K} 1$ \\
\hline
\end{tabular}


Türk Devletlerinin turizm sektörüne yatırım K14 yapabilme potansiyeli olan iş insanlarını yönlendirmek

Çat1 örgütün yürütme kurulu ve yönetim K31, K6 kurulunu oluşturmak, bu kurulların düzenli olarak toplanmasını sağlamak, turizm sektöründe ileriye dönük (uzun ve kısa vadede) planlamalar yapmak

Özel bir denetim komisyonu oluşturup turizm K18 işletmelerinin ortak standartlara ve sertifikasyon sistemlerine uyup uymadığını denetlemek

Tablo 10'a göre, katılımcıların çoğunluğu, Türk Devletlerinin turizm sektöründe bulunan birimleri ve kurumları bir araya getirip ülkeler arası koordinasyon ve iletişimi sağlamanın; Türk Devletleri arasında turizm sektörü için ortak bir plan ve projeler oluşturmanın; Türk halklarının ortak değerleri olan kültürel ve manevi miraslarını uluslararası seviyede tanıtmak ve kaynakların birleştirilip ülkelerin turistik değerlerinin tanıtımı ve pazarlamasını yapmanın söz konusu çatı örgütün görevleri arasında olması gerektiğini ifade etmiştir.

Ayrıca, üç katılımcı (K7, K16, K11) Türkiye'nin turizm sektörünün çok gelişmiş olduğunun altını çizerek kurulacak olan çatı örgüte Türkiye'nin liderlik yapması ve stratejilerin Türkiye'den katılan üyeler tarafından oluşturulmasını önermiştir. Üç katılımcı (K4, K22, K24) bu çatı örgüte devletler tarafından finansal desteğin ve bütçenin verilmesi gerektiği konusunda hem fikir olmuştur. Bir katılımcı (K13) bu örgütün herhangi bir kâr amacı gütmemesi gerektiğini belirtmiştir. Bir diğer katılımcı (K25) çatı örgütün koyduğu kuralların bütün Türk Devletlerinde yasal olarak geçerliliğinin sağlanabilmesi yönünde hukuki zeminin hazırlanması gerektiğini savunmuştur. Başka bir katılımcı (K29) bu ortak örgüt sayesinde taraf ülkelerin turizm sektörüne nasıl katkı sağlayacaklarını açık ve net bir şekilde ifade etme firsatı vereceğini belirtmiştir. Bir katılımcı (K3), söz konusu çatı örgütün önce Türkiye'de kurulmasını ve diğer Türk Devletlerine örnek olmasını önermiştir. Bu örgütün Türk Devletleri arasında millî şuuru oluşturup ve güçlendirmesini amaçlaması gerektiğini belirtmiştir. Çatı örgüt ismi için bir katılımcı (K24) “Türk Dünyası Turizm Konseyi” isminin koyulmasını önermiştir. 
Türk Dünyası Ülkeleri Arasında Seyahatlerin Kolaylaştırılmasına Yönelik Bulgular

Katılımcıların "Türk Dünyası ülkeleri arasında seyahatler nasıl kolaylaştırılabilir?” sorusuna verdikleri cevaplar aşağıda Tablo 11 'de gösterilmektedir.

\section{Tablo 11}

Türk Dünyası Ülkeleri Arasında Seyahatlerin Kolaylaştırılması için Verilen Öneriler

\section{Türk Dünyası Ülkeleri Arasında Seyahatlerin Kolaylaştırılması \\ Katılimcilar}

Demiryolu ve karayollarının

K12, K20, K21, K17, K18, K24, K16

geliştirilmesi

Uçak bilet fiyatlarının daha düşük olması ve Türk Devletlerinden gelen turistlere özel bir indirim sağlanması

Türk Devletlerindeki havayollarının gelişmesi için THY ile iş birliği yapilması

Hedef pazarlarda Türk Devletlerinin güvenli destinasyonlar olduğuna yönelik imaj çalışmalarının yapılması

Türk Devletleri arasında vize uygulamalarının kaldırılması veya kolaylaştırılması

Türk Devletlerine yönelik uçak sefer sayılarının (özellikle tarifeli seferlerin) çoğaltılması

Türk Devletlerinin ulaşım altyapıları için yatırımları ile ilgili faaliyetlerin başlatılması

Havaalanlarında ve diğer ulaşım K19, K30, K13, K14, K23, K21, K28, K11, K10, K24, K15, K6

K5

K5, K24

K30, K13, K1, K29, K20, K7, K28, $\mathrm{K} 27, \mathrm{~K} 8, \mathrm{~K} 23, \mathrm{~K} 9, \mathrm{~K} 17, \mathrm{~K} 18, \mathrm{~K} 11$, K6, K2

K4, K7, K28, K27, K5, K23, K9, K21, K17, K18, K10, K2, K3

K13

K22

araçlarında turist memnuniyeti için çalışan personellerin eğitimlerinin sağlanması

Türk Devletleri arasında tek bir turist vizesi oluşturulması

Yollarda verilen hizmetlerin (dinlenme tesisleri) kalitesinin ve niceliğinin arttırılması önerilmektedir 
Tablo 11'e bakıldığında katılımcılar çoğunlukla, havayolu dışında demiryolu ve karayollarının geliştirilmesini; uçak bilet fiyatlarının daha düşük olmasını ve Türk Devletlerinden gelen turistlere özel bir indirim sağlanmasını; Türk Devletleri arasında vize uygulamalarının kaldırılmasını veya kolaylaştırılmasını; Türk Devletlerine yönelik uçak sefer sayılarının (özellikle tarifeli seferlerin) çoğaltılmasını önermişlerdir. Bu öneriler yüzdeleriyle beraber Şekil 6’da gösterilmiştir.

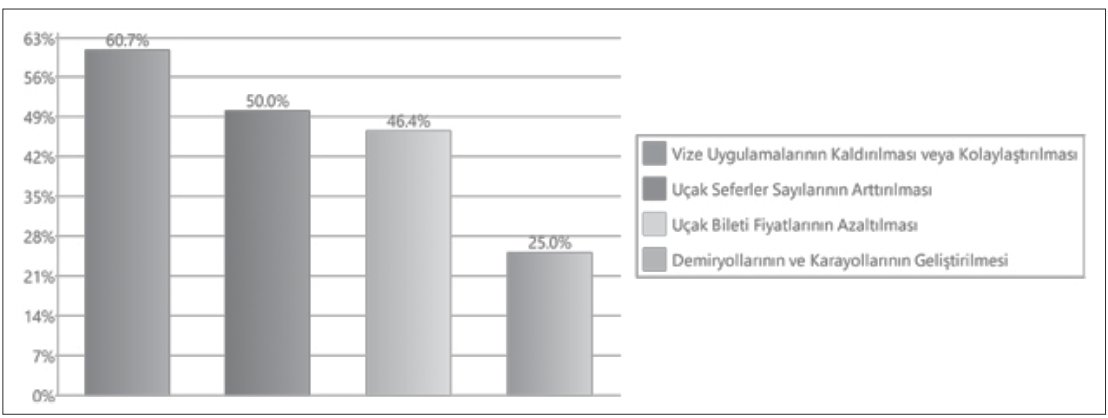

Şekil 6. Türk Dünyası Ülkeleri Arasında Seyahatlerin Kolaylaştırılmasına Yönelik Belirtilen Ana Öneriler

\section{Sonuç}

Türk Devletleri arasındaki ilişkilerin geliştirilmesinde "turizm" önemli bir potansiyele sahiptir. Çünkü turizm, toplulukların birbirlerine karşı edindiği önyargıları en aza indirerek ve daha pozitif algı yaratarak kültürel anlamda toplulukların bilincini arttırmaktadır. Bu nedenle turizm, Türk Devletleri arasındaki ilişkilerin ve farkındalıkların olumlu yönde ileriye gitmesinde kilit bir rol üstlenmektedir (Gülcan 113). Türk Devletlerinin ortak kökene sahip olması, aralarındaki turizm ilişkisinin geliştirilmesi ve büyük bir ekonomik güç yaratılması için önemlidir. 2020 yılı içerisinde Azerbaycan ve Ermenistan arasında çıkan Dağlık Karabağ Savaşını Azerbaycan'ın kazanması ve neticede yapılan anlaşmada Azerbaycan ve Nahcivan arasında kara ve demiryolu hattı açılması konusunda mutabakata bağlanması, Türk Dünyasında turizmin önemini belirginleştirmiştir. Bu yol sayesinde Türkiye; kara, demir ve denizyolu hatları ile Türk Dünyası ülkelerine doğrudan bağlanma imkanına kavuşmuştur. Dolayısıyla söz konusu ülkeler arasında yakın gelecekte turizm iş birliği yapılması önemini arttıracaktır. 
Bu çalışmada, Türk Devletlerinin turizm alanında iş birliğinin sağlanması için; hizmet standartlarının oluşturulması, kalifiye personel yetiştirilmesi, kamu ve özel sektör iş birliği, turizm altyapısının iyileştirilmesi, Türk Devletlerinden temsilcilerin periyodik olarak bir araya gelmesi ve turizm uzmanlarının deneyim alışverişi yapması konusunda öneriler verilmiştir.

Türk Devletlerinde bulunan turizm destinasyonlarının taraf ülkelerde tanıtımının ve pazarlamasının yapılması gerektiği konusunda bütün katılımcıların hemfikir olduğu görülmüştür. Bu tanıtımın ve pazarlamanın geliştirilmesi için, Türk Dünyası ülkelerinin cazibelerinin reklam kampanyaları ile tanıtılması; tanıtım ve pazarlama çalışmalarının dijital olarak yapılması, Türk Devletleri arasında periyodik olarak kongre, sergi ve fuar gibi etkinliklerin yapılması önerilmiştir. Ayrıca, Türk Devletlerinde turistler için daha fazla güvenlik tedbirlerinin alınması ve destinasyonların turistler için güvenli olduğuna yönelik tanıtımlar yapılması; hedef pazarlarda Türk Devletlerinin güvenli destinasyonlar olduğuna yönelik imaj çalışmalarının yapılmasının da gerekli olduğu konusunda görüşler belirtilmiştir. Bunlara ek olarak, Türk Devletlerinde çalışan acentelere teşvikler sunulmasının olumlu etkilere sahip olacağı da ifade edilmiştir.

Türk Devletleri arasında turizm eğitimi alanında öğrenci ve akademik personel değişim programlarının daha çok desteklenmesi; bu ülkelerde turizm eğitimi veren üniversitelerde müfredat birliğinin sağlanması ve bu ortak müfredatın sektör-akademi iş birliğinde oluşturulması; uzmanların deneyim ve tecrübelerini aktarmak için özel sektörde değişim programlarının yapılması önerilmiştir. Türk Devletleri arasında turizm iş birliğine yönelik bir çatı örgütün kurulmasının ilgili ülkelere katkı sağlayacağı konusunda katılımcıların \%90,3'ü hemfikir olmuştur. Bu çatı örgüt için örnek alınabilecek birlikler; Dünya Turizm Örgütü, TÜRKSOY, Türk Konseyi, UFTAA ve Avrupa Birliği olarak önerilmiştir. Çatı örgüte üye olacak kişi ve kurumlar için ise ülkelerin Turizm Bakanlığı temsilcileri; acente, otel vb. birlikleri; turizm ve ilgili alanlardan akademisyenler ile konsolosluklardan temsilciler önerilmiştir.

Türk Devletlerinin turizm sektöründe bulunan birimlerini ve kurumlarını bir araya getirip ülkeler arası koordinasyon ve iletişimi sağlamak; Türk Devletleri arasında turizm sektörü için ortak plan ve projeler oluşturmak; Türk halklarının ortak değerleri olan kültürel ve manevi miraslarının uluslararası 
seviyede tanıtmak ve kaynakların birleştirilip ülkelerin turistik değerlerinin tanıtımı ve pazarlamasını yapmak gibi faaliyetlerin söz konusu çatı örgütün görevleri arasında olması gerektiği ifade edilmiştir. Türk Devletleri arasında seyahatlerin kolaylaştırılması için havayolu dışında demiryolu ve karayollarının geliştirilmesi; uçak bilet fiyatlarının düşürülmesi ve Türk Devletlerinden gelen turistlere özel indirimlerin sağlanması; Türk Devletleri arasında vize uygulamalarının kaldırılması veya kolaylaştırılması ve Türk Devletlerine yönelik uçak sefer sayılarının çoğaltılması önerilmiştir.

Sonuç olarak, Türk Dünyasında turizmde iş birliği ruhunun geliştirilmesi için söz konusu devletleri uluslararası ortak bir çatı örgüt altında toplama önerisi, bu çalş̧madan elde edilen en önemli sonuçtur. Çünkü uluslararası ilişkilerde devletlerden sonra en fazla rolü uluslararası örgütler almaktadır. Ayrıca, bu çalışmada elde edilen bulgular, bu konuda yapılan diğer araştırma bulgularıyla (Zorlu 196, Aydemir ve Yaşar 56, Gülcan 119, Sancar vd. 294-296, Erol ve Çelik 16) paralellik göstermektedir.

Bu alanda benzer çalışma olmasına karşın bu çalışmadaki gibi Türk Dünyası ülkelerinden turizm sektöründe uzmanlaşmış kişilerle kendi ülkelerinin turizminin tüm boyutları hakkında derin görüşmeleri içeren kapsamlı ve detaylı bir çalışma bulunmaması, bu çalışmanın alan yazına teorik katkısı olarak görülmektedir. Ek olarak bu çalışma, politika geliştiricilerin Türk Dünyası ülkelerinin turizm iş birliğinin güçlendirilmesinin gerekliliğini görmeleri konusunda politika düzeyinde uygulamaya katkı sağlamaktadır. $\mathrm{Bu}$ çalışma sayesinde ülkeler turizm sektörlerinin güçlü ve zayıf yönlerini görebilir ve turizmi geliştirmek için önerilen yolları uygulamaya koymak için çalışmalar başlatabilirler.

Türk Devletlerinden 31 katılımcının görüşleri alınarak oluşturulan bu çalışma kapsamında katılımcıların görüşleri doğrultusunda aşağıda sıralanan öneriler de getirilebilir:

- Türk Devletleri arasında turizm sektörünün daha rekabetçi olabilmesi adına Türk Dünyası Turizm Birliği kurulmalıdır.

- Türk Dünyası Turizm Birliği, Türk devletlerinin tanıtımına ve Türk Dünyası turizminin uluslararası ölçekte pazarlanmasına katkı sağlayabilecektir. 
- Yeni turistik destinasyonların Türk Dünyası Turizm Destinasyonları adı altında bir rota veya konsept halinde sunulacak olması ve ilaveten Türk Devletleri vatandaşlarına turizm faaliyetleri amacıyla eşit şartlarda serbest dolaşım hakkının verilmesi, hem Türk Devletlerinde turizm anlayışının gelişmesine hem de turizmden daha fazla gelir elde etmelerine katkı sağlayabilecektir.

- Türk Devletleri arasında turizm sektörüne yönelik ortak mesleki, yaygın veya örgün eğitim programlarının uygulamalı ve teorik boyutta yapılandırılması hem sektörde kalifiye personelin istihdam edilmesine hem de staj ya da öğrenci değişimlerine yönelik firsatlar oluşturabilecektir.

- Türk Dünyası Turizm Birliği, ilk etapta turizm birliği çatısını hedeflese de ilerleyen dönemlerde Türk Devletleri ile yeni iş birliği çalışmalarının yapılmasına da katkı sağlayabilecektir.

- Türk Dünyası Turizm Birliği, Türk halklarının birbirlerine olan güven duygularını resmi ve STK'lar üzerinden geliştirecek olup, aslında geçmişten günümüze aynı kültürel öğelere sahip olan Türk Dünyasında halkların birbirini tanımasına ve farkındalıklarının artarak geliştirmesine sebep olabilecektir.

- Türk Dünyası Turizm Birliği sayesinde Türk Devletleri arasında yeni bölgelere ve destinasyonlara, alanlara özgü rehberlik gibi birçok istihdam alanları doğuracaktır.

\section{Kaynaklar}

Akdağ, Gürkan vd. "Turizme Genel Bakış." Kavramlar ve Örneklerle Genel Turizm, ed. A. D. Çakıcı, Detay Yayıncılık, 2019, ss. 1-26.

Ammirato, Salvatore vd. "Tourism destination management: A collaborative approach.” Working Conference on Virtual Enterprises, Springer, 2014, pp. 217-226.

Aydemir, Burhan, ve İrfan Yaşar. "Dış Politika ve Turizm İlişkisi Bağlamında Türkiye'nin Asya Ülkeleri ile Yaptığı Turizm Anlaşmalarının Değerlendirilmesi." Balıkesir Üniversitesi Sosyal Bilimler Enstitüsü Dergisi, vol. 19 no. 36-1, 2016, ss. 39-59.

Aytaçlı, Berrak. "Durum Çalışmasına Ayrıntılı Bir Bakış." Adnan Menderes Üniversitesi Eğitim Fakültesi Eğitim Bilimleri Dergisi, vol. 3 no. 1, 2012, ss. $1-9$. 
Baltacı, Ali. "Nitel Araştırma Süreci: Nitel Bir Araştırma Nasıl Yapılır?” Ahi Evran Üniversitesi Sosyal Bilimler Enstitüsü Dergisi, vol. 5 no. 2, 2019, ss. 368-388.

Braun, Virginia, ve Victoria Clarke. "Psikolojide Tematik Analizin Kullanımı." Çev. Nihad Şad, Niyazi Özer, ve Abdullah Atli. Eğitimde Nitel Araştırmalar Dergisi, vol. 7 no. 2, 2019, ss. 873-898.

Bümen, Nilay, ve Ümran Yazıcılar. "Öğretmenlerin Öğretim Programı Uyarlamaları Üzerine Bir Durum Çalışması: Devlet ve Özel Lise Farklılıkları.” Gazi University Journal of Gazi Educational Faculty (GUJGEF), vol. 40 no. 1, 2020, ss. 183-224.

Büyüköztürk, Şener. “Örnekleme Yöntemleri.” 2012, http://cv.ankara.edu.tr/ duzenleme/kisisel/dosyalar/21082015162828.pdf

Creswell, John W. Research Design: Qualitative, Quantitative and Mixed Methods Approaches. Thousands Oaks, CA: SAGE Publications, 2009.

Çokluk, Ömay vd. "Nitel Bir Görüşme Yöntemi: Odak Grup Görüşmesi.” Kuramsal Ë̆itimbilim Dergisi, vol. 4 no. 1, 2011, ss. 95-107.

Erol, Mehmet S., ve Kadir Ertaç Çelik. “Türk Dünyası'nda İşbirliği Denemesi: Türk Keneşi ve Kazakistan.” Türk Dünyası İncelemeleri Dergisi, vol. 17 no. 2, 2017, ss. 15-32.

Fyall, Alan vd. "Destination Collaboration: A Critical Review of Theoretical Approaches to a Multi-Dimensional Phenomenon." Journal of Destination Marketing \& Management, vol. 1 no. 1-2, 2012, pp. 10-26.

Gülcan, Bilgehan. “Türk Dünyası İlişkilerinde Kritik Faktör Olarak Turizm.” Yükselen İpek Yolu: İpek Yolu’nda Ekonomi ve Turizm, ed. Fahri Atasoy, Türk Yurdu Yayınları, 2016, ss. 113-120.

İlker, Gamze. "Küreselleşme Sürecinde Stratejik İşbirlikleri." Selçuk Üniversitesi Sosyal Bilimler Meslek Yüksek Okulu Dergisi, vol. 13 no. 1-2, 2010, ss. 191220.

Kıroğlu, Kasım, Alper Kesten, ve Cevat Elma. "Türkiye’de Öğrenim Gören Yabancı Uyruklu Lisans Öğrencilerinin Sosyo-Kültürel ve Ekonomik Sorunları.” Mersin Üniversitesi Ĕ̆itim Fakültesi Dergisi, vol. 6 no. 2, 2010, ss. 26-39.

Kreag, Glenn. “The Impacts of Tourism. Minnesota Sea Grant.” 2001, http://www. seagrant.umn.edu/tourism/pdfs/ImpactsTourism.pdf

Leung, Lawrence. "Validity, Reliability, and Generalizability in Qualitative Research.” Journal of Family Medicine and Primary Care, vol. 4 no. 3, 2015, pp. 324-327.

Marzuki, Azizan. "Impacts of Tourism Development." Anatolia, vol. 20, no. 2, 2009, pp. 450-455.

Miles, Matthew B., and A. Michael Huberman. An Expanded Sourcebook: Qualitative Data Analysis. Thousand Oaks, CA: SAGE Publications, 1994. 
Ozan Leymun, Şenay vd. "Eğitim Ortamlarında Durum Çalışmasının Önemi." Eğitimde Nitel Araştırmalar Dergisi, vol. 5 no. 3, 2017, ss. 367-385.

Özdemir, Murat (2010). "Nitel Veri Analizi: Sosyal Bilimlerde Yöntembilim Sorunsalı Üzerine Bir Çalışma.” Eskişehir Osmangazi Üniversitesi Sosyal Bilimler Dergisi, vol. 11, no. 1, 2010, ss. 323-343.

Sancar, Muhammed Fatih vd. "Orta Asya Türk Devletleri ile Türkiye Arasındaki Turizm Potansiyeli ve Ekonomi Açısından İncelenmesi." Avrasya Ekonomisi Uluslararası Konferansi, 2015, ss. 291-297.

Shenton, Andrew K. "Strategies for Ensuring Trustworthiness in Qualitative Research Projects." Education for Information, vol. 2, no. 2, 2004, pp. 63-75. Sönmez, Sevil F., and Yorghos Apostolopoulos. "Conflict Resolution Through Tourism Cooperation? The Case of the Partitioned Island-State of Cyprus." Journal of Travel \& Tourism Marketing, vol. 9 no. 3, 2000, pp. 35-48.

Subaşı, Münevver, ve Kübra Okumuş. "Bir Araştırma Yöntemi Olarak Durum Çalışması.” Atatürk Üniversitesi Sosyal Bilimler Enstitüsü Dergisi, vol. 21, no. 2, 2017, ss. 419-426.

Şen, Mehmet, ve Ceren Öztekin. "Bağlam Bilgisi ve Pedagojik Alan Bilgisi Etkileşimi: Sosyokültürel Yaklaşım.” Eğitim ve Bilim, vol. 44 no. 198, 2019, ss. 57-97.

T.C. Dışişleri Bakanlığı. “Türk Konseyi.” (Türk Dili Konuşan Ülkeler İşbirliği Konseyi), 2020, http://www.mfa.gov.tr/turk-konseyi.tr.mfa

Timothy, Dallen J. "Cooperative Tourism Planning in a Developing Destination.” Journal of Sustainable Tourism, vol. 6, no. 1, 1998, pp. 52-68.

TÜRKKON. “Turizm.” 2020, https://www.turkkon.org/tr/isbirligi-alanlari/ turizm_6

TÜRKKON. “Turizm.” 31.10.2020, https://www.turkkon.org/tr/isbirligi-alanlari/ turizm_6

TÜRKPA. “Tarihçe.” 31.10.2020, https://turk-pa.org/tr/content/about_turkpa/ history

TÜRKSOY. "Hakkında”, 2020, https://www.turksoy.org/tr/turksoy/about

TWESCO. "Akademi Hakkında.” 2020, http://twesco.org/tr/\%d0\%b0\%d0\%ba \%d0\%b0\%d0\%b4\%d0\%b5\%d0\%bc\%d0\%b8\%d1\%8f-\%d1\%82\%d1\% $83 \% \mathrm{~d} 1 \% 80 \% \mathrm{~d} 0 \% \mathrm{~b} 0 \% \mathrm{~d} 0 \% \mathrm{bb} \% \mathrm{~d} 1 \% 8 \mathrm{~b} /$

Wheeler, Thomas. Turkey's Role and Interests in Central Asia. Saferworld Briefing, 2013.

Yağar, Fedayi, ve Sema Dökme. "Niteliksel Araştırmaların Planlanması: Araştırma Soruları, Örneklem Seçimi, Geçerlik ve Güvenirlik." Gazi Sağlık Bilimleri Dergisi, vol. 3, no. 3, 2013, ss. 1-9. 
Yaşar, Münevver Can vd. "Çocuk Gözüyle Tabiat Anaya Geri Dönüş." Eğitim ve Öğretim Araşttrmaları Dergisi, vol. 1, no. 2, 2012, ss. 30-40.

Yılmaz, Murat. "Türkiye ile Türk Cumhuriyetleri Arasındaki Turistik Hareketlere Coğrafi Bir Bakış." Journal of International Social Research, vol. 11, no. 59, 2018, ss. 406-412.

Zemla, Michal. "Inter-Destination Cooperation: Forms, Facilitators and InhibitorsThe Case of Poland." Journal of Destination Marketing \& Management, vol. 3, no. 4, 2014, pp. 241-252.

Zhong, Linsheng vd. "Research on Environmental Impacts of Tourism in China: Progress and Prospect." Journal of Environmental Management, vol. 92, no. 11, 2011, pp. 2972-2983.

Zorlu, Kürşad. "Türk Dünyasında Turizm İşbirliğinin Geliştirilmesine Yönelik Bir Araştırma." Journal of Tourism and Gastronomy Studies, vol. 6, no. 1, 2018, ss. 182-199. 


\title{
A Qualitative Research on the Cooperation-Based Development of Tourism in the Turkic World Countries*
}

Muharrem Tuna**

Başak Özyurt **

Ayşe Selin Dülger

Fatih Türkmen

Necmi Uyanık

\begin{abstract}
The main purpose of the study is to determine the existing tourism potential of Azerbaijan, Kazakhstan, Kyrgyzstan, Cyprus, Turkey and Uzbekistan and to underline the importance of cooperation in the field of tourism. In this study, criteria sampling method and maximum diversity sampling method, which are among the purposeful sampling methods, were used in determining the sample. In addition, a case study, one of the qualitative research designs, was used. In the study, after in-depth interviews were
\end{abstract}

\footnotetext{
Date of Arrival: 31 January 2021 - Date of Acceptance: 20 May 2021

You can refer to this article as follows:

Tuna, Muharrem et al. "Türk Dünyasında Turizmin Ülkeler Arası İş Birliği Temelli

Geliştirilmesine Yönelik Nitel Bir Araşıırma.” bilig, no. 100, 2022, pp. 137-176.

* Prof. Dr., Ankara Hacı Bayram Veli University, Faculty of Tourism, Department of Tourism

Management - Ankara/Turkey

ORCID: 0000-0001-5526-7122

muharrem.tuna@hbv.edu.tr

.** Res. Asst., Trakya University, Faculty of Applied Sciences, Department of Tourism Management Edirne/Turkey ORCID: 0000-0003-3225-0250 basakozyurt1@trakya.edu.tr

Res. Asst., Ankara Hacı Bayram Veli University, Faculty of Tourism, Department of Tourism Management - Ankara/Turkey ORCID: 0000-0001-8897-013X ayse.dulger@hbv.edu.tr

Assoc. Prof. Dr., Karabük University, Safranbolu Faculty of Tourism, Department of Tourism Management - Karabük/Turkey ORCID: 0000-0001-6716-7399 fatihturkmen@karabuk.edu.tr

*n*** Prof. Dr., Selçuk University, Faculty of Literature, Department of History - Konya/Turkey ORCID: 0000-0003-3692-3168 necmiuyanik@hotmail.com
} 
conducted with 31 people from six different Turkish states, including tourism academics, ministry representatives and managers working in the tourism sector, thematic analysis was conducted using the MAXQDA 2020 qualitative data analysis program. As a result of the study, it was stated that cooperation in the field of tourism will contribute to the development of economies and the maintenance of political unity in Turkish states. Furthermore, it was realized that the tourism destinations in these countries should be promoted and marketed in various ways and an umbrella organization for tourism cooperation needs to be established.

\section{Keywords}

Turkish States, Turkic World, tourism, cooperation, tourism planning. 


\title{
Качественное исследование
}

\section{международного сотрудничества в развитии туризма в странах тюркского мира*}

\author{
Мухаррем Туна \\ Башак Озйурт ${ }^{* * *}$ \\ Айше Селин Дюльгер \\ Фатих Тюркмен \\ Неджми Уянык
}

\begin{abstract}
Аннотация
Основная цель исследования - определить существующий туристический потенциал Азербайджана, Казахстана, Кыргызстана, Кипра, Турции и Узбекистана и подчеркнуть важность сотрудничества в сфере туризма. В этом исследовании для определения выборки использовались метод выборки по критериям и метод выборки с максимальным разнообразием, которые входят в число целевых методов выборки. Кроме того, использовался тематический анализ, как один из видов качественного исследования. В
\end{abstract}

* Поступило в редакцию: 31 января 2021г. - Принято в номер: 20 мая 2021 г.

Ссылка на статью:

Tuna, Muharrem et al. "Türk Dünyasında Turizmin Ülkeler Arası İş Birliği Temelli Geliştirilmesine Yönelik Nitel Bir Araştırma.” bilig, no. 100, 2022, pp. 137-176.

** Проф., д-р, Университет Анкары Хаджи Байрам Вели, факультет туризма, кафедра управления туризмом - Анкара / Турция

ORCID: 0000-0001-5526-7122

muharrem.tuna@hbv.edu.tr

*** Ассистент, Университет Тракья, Факультет прикладных наук, кафедра управления туризмом - Эдирне / Турция

ORCID: 0000-0003-3225-0250

basakozyurt1@trakya.edu.tr

**** Ассистент, Университет Анкары Хаджи Байрам Вели, факультет туризма, кафедра управления туризмом - Анкара / Турция

ORCID: 0000-0001-8897-013X

ayse.dulger@hbv.edu.tr

***** Доц., д-р, Карабюкский университет, факультет туризма Сафранболу, кафедра управления туризмом - Карабюк / Турция ORCID: 0000-0001-6716-7399 fatihturkmen@karabuk.edu.tr

****** Проф., д-р, Сельджукский Университет, факультет литературы, кафедра истории - Конья / Турция ORCID: 0000-0003-3692-3168

necmiuyanik@hotmail.com 
исследовании, после того как были проведены углубленные интервью с 31 корреспондентом из шести различных тюркских государств, включая ученых в области туризма, представителей министерств и менеджеров, работающих в туристическом секторе, был проведен тематический анализ с использованием программы анализа качественных данных MAXQDA 2020. В результате исследования было выявлено, что сотрудничество в сфере туризма будет способствовать развитию экономики и поддержанию политического единства в тюркских государствах. Кроме того, было осознано, что туристические направления в этих странах следует продвигать и продавать различными способами, и необходимо создать зонтичную организацию для сотрудничества в сфере туризма.

\section{Ключевые слова}

Тюркские государства, тюркский мир, туризм, сотрудничество, планирование туризма. 